Review article

\title{
Obesogens in the aquatic environment: an evolutionary and toxicological perspective
}

\author{
Ana Capitão $^{\mathrm{a}, \mathrm{b}, *}$, Angeliki Lyssimachou ${ }^{\mathrm{a}}$, Luís Filipe Costa Castro ${ }^{\mathrm{a}, \mathrm{b}, *}$, Miguel M. Santos ${ }^{\mathrm{a}, \mathrm{b}, *}$ \\ a CIMAR/CIIMAR-Interdisciplinary Centre of Marine and Environmental Research, University of Porto, Terminal de Cruzeiros do Porto de Leixões, Avenida General \\ Norton de Matos, S/N, 4450-208 Matosinhos, Portugal \\ ${ }^{\mathrm{b}}$ FCUP - Department of Biology, Faculty of Sciences, University of Porto, Rua do Campo Alegre, 4169-007 Porto, Portugal.
}

\section{A R T I C L E I N F O}

\section{Keywords:}

Obesogens

Endocrine disruption

Evolution

Nuclear receptor

Lipid metabolism

Aquatic animals

\begin{abstract}
A B S T R A C T
The rise of obesity in humans is a major health concern of our times, affecting an increasing proportion of the population worldwide. It is now evident that this phenomenon is not only associated with the lack of exercise and a balanced diet, but also due to environmental factors, such as exposure to environmental chemicals that interfere with lipid homeostasis. These chemicals, also known as obesogens, are present in a wide range of products of our daily life, such as cosmetics, paints, plastics, food cans and pesticide-treated food, among others. A growing body of evidences indicates that their action is not limited to mammals. Obesogens also end up in the aquatic environment, potentially affecting its ecosystems. In fact, reports show that some environmental chemicals are able to alter lipid homeostasis, impacting weight, lipid profile, signaling pathways and/or protein activity, of several taxa of aquatic animals. Such perturbations may give rise to physiological disorders and disease. Although largely unexplored from a comparative perspective, the key molecular components implicated in lipid homeostasis have likely appeared early in animal evolution. Therefore, it is not surprising that the obesogen effects are found in other animal groups beyond mammals. Collectively, data indicates that suspected obesogens impact lipid metabolism across phyla that have diverged over 600 million years ago. Thus, a consistent link between environmental chemical exposure and the obesity epidemic has emerged. This review aims to summarize the available information on the effects of putative obesogens in aquatic organisms, considering the similarities and differences of lipid homeostasis pathways among metazoans, thus contributing to a better understanding of the etiology of obesity in human populations. Finally, we identify the knowledge gaps in this field and we set future research priorities.
\end{abstract}

\section{Introduction}

\subsection{Endocrine disruption}

The steep increase of chemical production and use since the 1940s coincides with the rise of several endocrine-related disorders in humans and wildlife populations, suggesting a relationship between both events (Bergman et al., 2013; Diamanti-Kandarakis et al., 2009; Grün and Blumberg, 2006; Kabir et al., 2015). The number of studies supporting this hypothesis is growing and it is now established that several of these chemicals have endocrine disrupting properties (Bergman et al., 2013). Endocrine disrupting chemicals (EDC) interfere with the normal

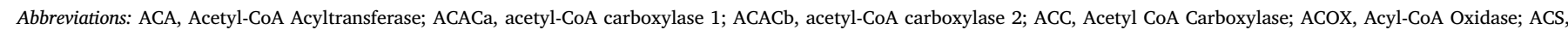

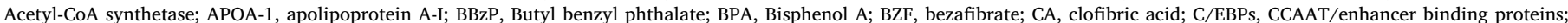

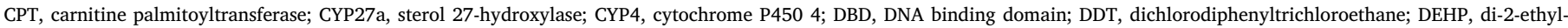

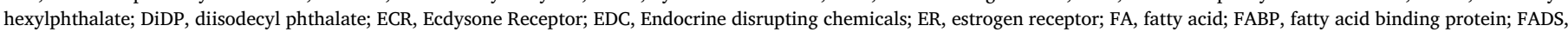

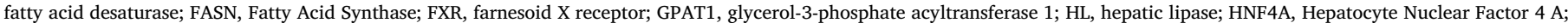

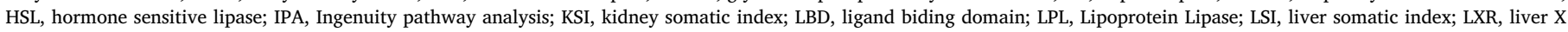

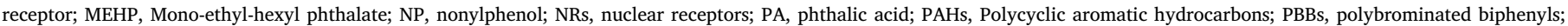

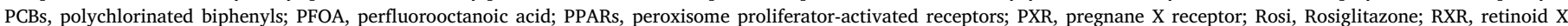

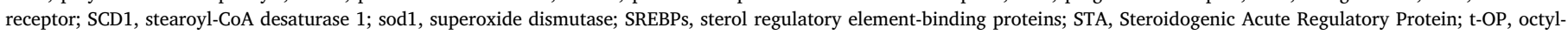

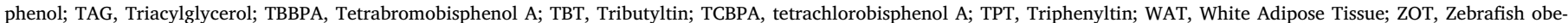
sogenic test

* Corresponding authors at: CIMAR/CIIMAR- Interdisciplinary Centre of Marine and Environmental Research, University of Porto, Terminal de Cruzeiros do Porto de Leixões, Avenida General Norton de Matos, S/N, 4450-208 Matosinhos, Portugal.

E-mail addresses: acapitao@ciimar.up.pt (A. Capitão), filipe.castro@ciimar.up.pt (L.F.C. Castro), santos@ciimar.up.pt (M.M. Santos). 
function of the endocrine system by mimicking, blocking and/or altering hormone roles and metabolism (Diamanti-Kandarakis et al., 2009; Kabir et al., 2015; Schug et al., 2011). Although more than 1300 chemicals have been identified to potentially interfere with hormonal metabolism, very few have been screened for their capacity to cause endocrine effects in vivo (Bergman et al., 2013; "TEDX The Endocrine Disrupting Exchange," 2017).

This vast number of compounds identified as EDCs have distinct chemical structures, proprieties and applications. Some of these compounds are used as synthetic hormones (e.g. ethynilestradiol), plastics (e.g. bisphenol A (BPA), phthalates), pesticides and fungicides (e.g.: organotins, methoxychlor, chlorpyrifos, dichlorodiphenyltrichloroethane (DDT), vinclozolin), solvents (e.g.: polychlorinated biphenyls (PCBs), polybrominated biphenyls (PBBs), dioxins), pharmaceutical agents (e.g. thiazolidinediones, atypical anti-psychotics, antihistamines, antidepressants) and personal care products (e.g. triclosan). Besides synthetic chemicals, some natural compounds are also known EDCs (e.g. phytoestrogens, including genistein and coumestrol) (Castro and Santos, 2014; Kabir et al., 2015; Schug et al., 2016). Several of these compounds can undergo bioaccumulation and biomagnification through the food-chain, being persistent in the environment. In contrast, others are easily degraded but their continuous release into the environment still makes them a cause of concern (Bergman et al., 2013; Diamanti-Kandarakis et al., 2009; Kabir et al., 2015) (See Fig. 1).

The effects of different EDCs in non-target organisms have been well documented (Ferreira et al., 2009; Liu et al., 2014; Melvin, 2016; Rodrigues et al., 2006; Schug et al., 2016). Two well-known examples targeting the reproductive system are organotins that cause imposex in gastropods mollusks (a condition characterized by the development of male secondary sexual characteristics in females) (Abidli et al., 2009; Lima et al., 2011; Pascoal et al., 2013), and ethinylestradiol that alters the fecundity and sex ratio of fish (Runnalls et al., 2015; Soares et al., 2009). Alterations in gene and protein expression, as well as physiological and behavioral changes are also observed frequently as a consequence of EDC exposure (Brander, 2013; Sárria et al., 2013). More recently, evidences emerged regarding disruption in lipid homeostasis by EDCs. Since lipid metabolism dysregulation is related with several important diseases in the human population, the mode of action of these compounds - also known as obesogens- is now under strong scrutiny (Castro and Santos, 2014; De Cock and Van de Bor, 2014; Diamanti-Kandarakis et al., 2009; Grün and Blumberg, 2006; OuadahBoussouf and Babin, 2016; Santos et al., 2012). These compounds can increase the number of fat cells and/or the amount of fat stored in each cell by altering the pathways of energy metabolism and food intake
(Holtcamp, 2012; Janesick and Blumberg, 2011). Several mechanisms of action have been suggested, including epigenetic changes that will be inherited by the future generations (Holtcamp, 2012). However, only a small portion of chemicals has been tested so far for their potential to disrupt lipid homeostasis and a considerable amount of those fall in the obesogens category, such as organotins, BPA, perfluorooctanoic acid (PFOA), phthalates and some pharmaceuticals (Bašić et al., 2012; Bergman et al., 2013; Legler et al., 2015).

\subsection{Lipid homeostasis}

Lipid homeostasis is vital for the normal development, maintenance and reproduction of metazoans, given their transversal involvement in a great variety of metabolic processes, such as energy storage, membrane composition, as intracellular signaling molecules, enzyme cofactors and several others (Birsoy et al., 2013). In vertebrates, lipid metabolism is tightly regulated so that the organism can meet its physiological needs (Castro et al., 2016; Mello, 2010; Santos et al., 2012) (see Fig. 2). This metabolic regulation involves three major forms (Desvergne et al., 2006):

a. Allosteric control of enzyme activity along a metabolic pathway through the binding of an activator (for example, the enzyme-substrate);

b. Post-translational modifications, which activate/deactivate the enzyme;

One example is the phosphorylation/dephosphorylation of Acetyl CoA Carboxylase (ACC). Low glucose levels cause the dephosphorylation of ACC down-regulating the fatty acid synthesis, while high glucose levels cause the opposite response. This regulation is essential in the balance between $\beta$-oxidation and fatty acid (FA) synthesis. (Berg et al., 2002; Nelson et al., 2005).

\section{c. Transcriptional regulation;}

This regulation of lipid metabolism occurs through the action of several transcription factors, including nuclear receptors (NRs), sterol regulatory element-binding proteins (SREBPs) and CCAAT/enhancer binding proteins (C/EBPs) (Desvergne et al., 2006). The transcription factors can up or down-regulate the transcription of specific genes and protein synthesis (Lempradl et al., 2015; Lyssimachou et al., 2015). NRs include peroxisome proliferator-activated receptors (PPARs), pregnane $\mathrm{X}$ receptor (PXR), liver $\mathrm{X}$ receptor (LXR), farnesoid $\mathrm{X}$ receptor (FXR), all

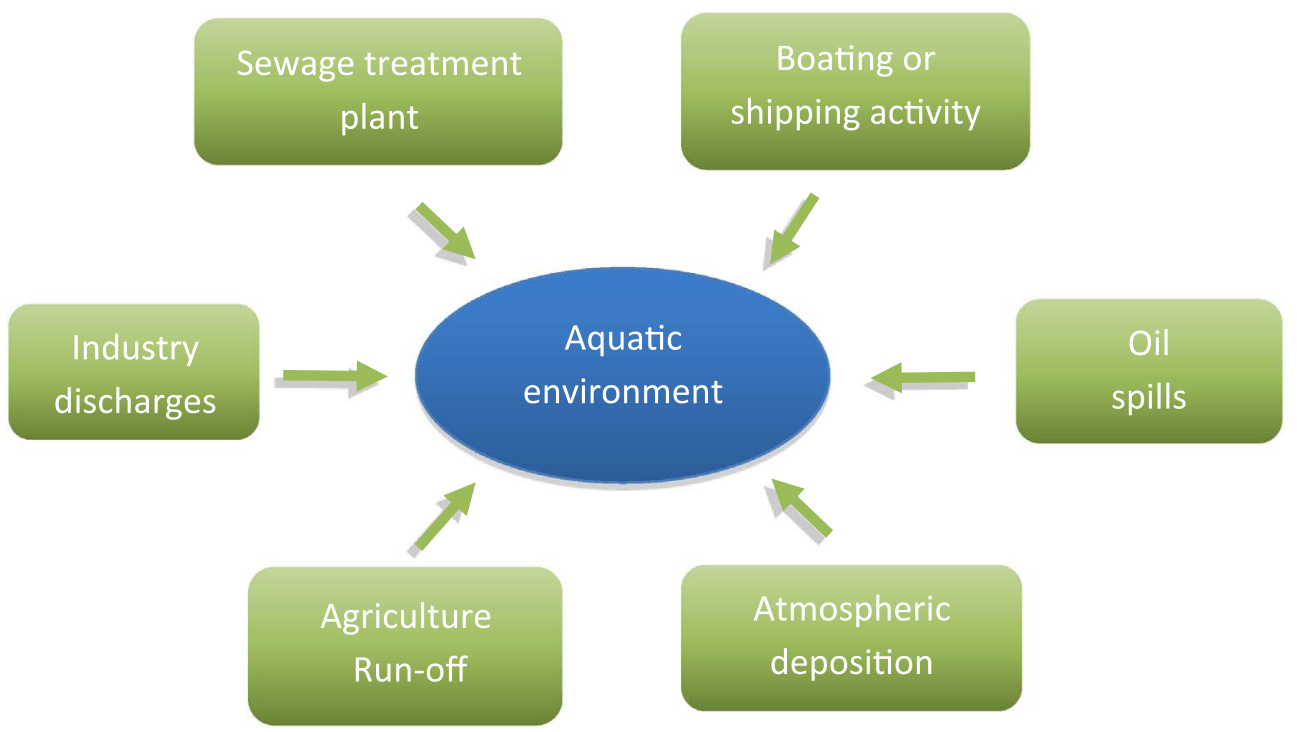

Fig. 1. Schematic illustration of EDCs input in the aquatic environment (lakes, rivers and sea) (modified from Pait and Nelson, 2002; Sumpter, 2005). 


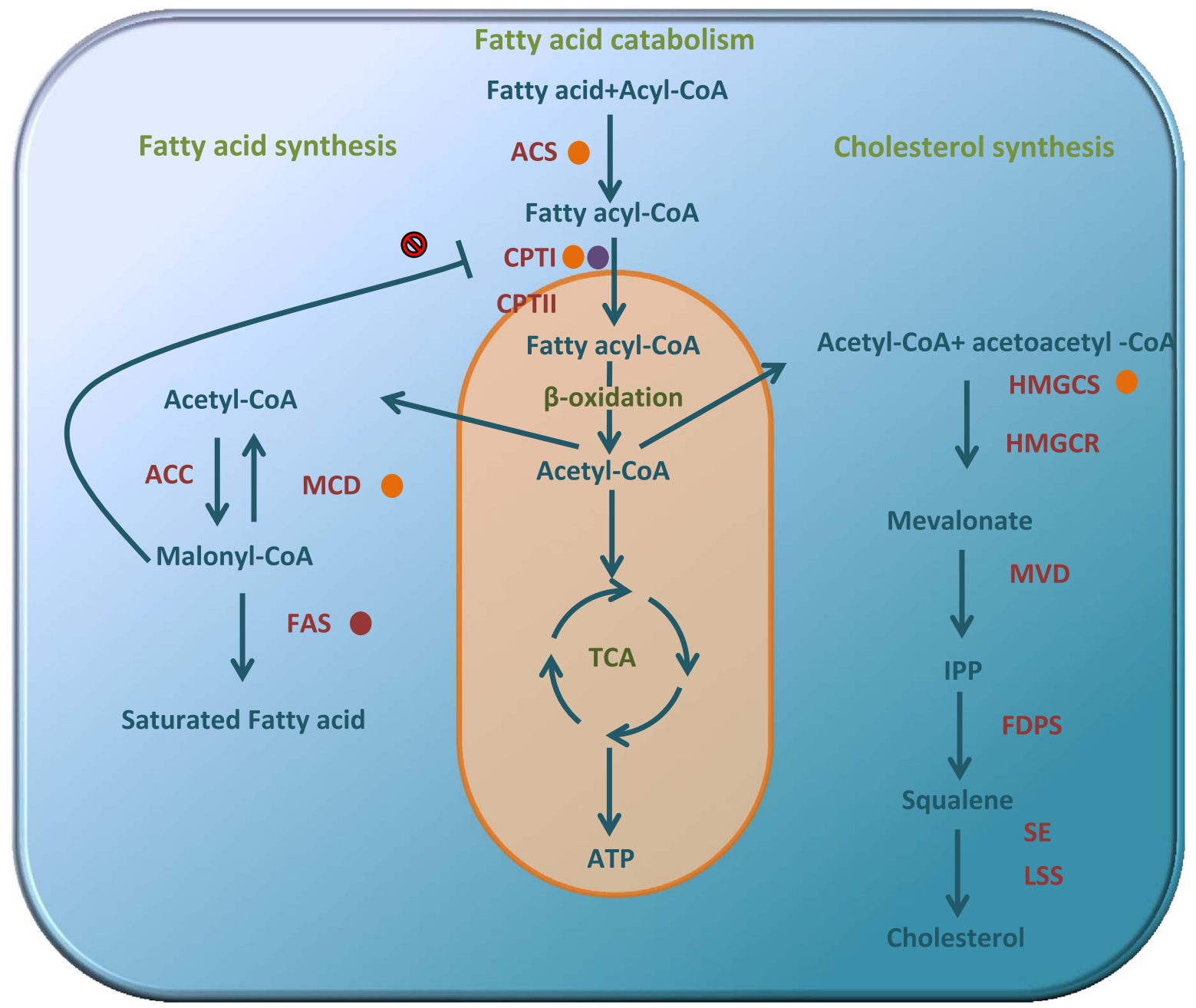

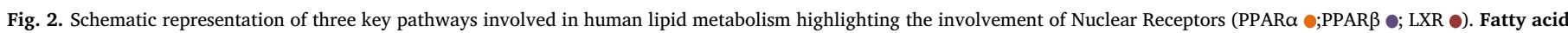

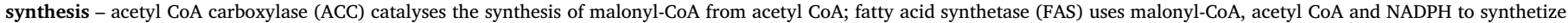

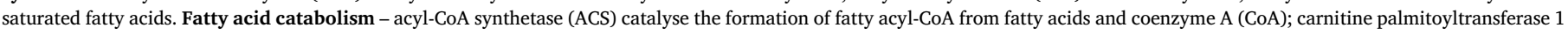

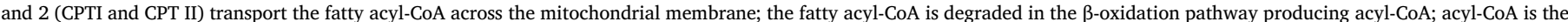

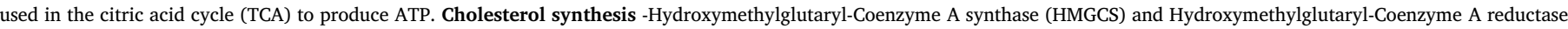

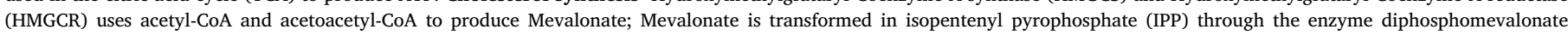

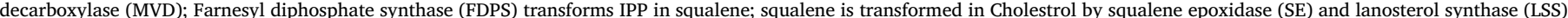
(Based on (Alaynick, 2008; Berkenstam and Gustafsson, 2005; Birsoy et al., 2013; Desvergne et al., 2006; Mello, 2010; Shi and Burn, 2004).

heterodimeric partners of retinoid X receptor (RXR), among others. The PPARs are crucial in the regulation of fat storage and FA $\beta$-oxidation. Mammals display three different PPAR genes: PPAR $\alpha$ regulates enzymes involved in the up-take of fatty acids, fatty acid esterification and $\beta$-oxidation; PPAR $\beta$ regulates FA oxidation in the muscles and PPAR $\gamma$ regulates and is essential for adipogenesis. In vertebrates, in addition to function as an xenobiotic sensor, PXR is also involved in the regulation of lipid homeostasis in the liver and in the regulation of PPAR $\gamma$ gene expression (Carazo et al., 2017; Mello, 2010). LXR, FXR and SREBP-2 play a key role in cholesterol homeostasis; LXR regulates the expression of SREBP-1c (Eberlé et al., 2004), while FXR activates the expression of PPARa. C/EBPs are involved in adipogenesis and can activate the expression of PPAR $\gamma$ (Nerlov, 2007) and SREBP-1c apart from cholesterol is also involved in the fatty acid synthesis (Reviewed by Alaynick, 2008; Berkenstam and Gustafsson, 2005; Desvergne et al., 2006; Mello, 2010).

\subsection{Obesogens}

Although this research area is relatively recent, several in vitro and in vivo studies have already shown the effect of obesogens in vertebrates (Chamorro-García et al., 2013; Grün and Blumberg, 2009a, 2009b). The differentiation of 3T3-L1 cells in adipocytes is stimulated in the presence of several putative obesogenic compounds such as organotins (Tributyltin (TBT) and Triphenyltin (TPT)) (Pereira-Fernandes et al., 2013), phthalates (Mono-ethyl-hexyl phthalate (MEHP), mono-benzyl phthalate and mono-sec-butyl phthalate) (Hurst and Waxman, 2003) and BPA (Masuno et al., 2005). Several in vivo observations support these in vitro results. Chamorro-Garcia and co-workers studied the effect of TBT and Rosiglitazone (Rosi) (a therapeutic drug and PPAR $\gamma$ agonist) throughout 3 generations of C57/6J mice. The parental generation (F0) was exposed to TBT (5.42, 54.2 and $542 \mathrm{nM}$ ) or Rosi (500 nM), the offsprings (F1) were exposed in utero, F2 was exposed as germ cells and F3 was not exposed at all. All 3 generations (F1, F2 and F3) from the TBT parental exposure presented, to some extent, an increase in the white adipocyte tissue (WAT), liver lipids and alteration in the expression profile of several genes involved in lipid metabolism (Ppara, Ppary, Lipoprotein Lipase (Lpl), Srebp1c, Acyl-CoA Oxidase (Acox) and Fatty Acid Synthase (Fasn)). Similar results, although less pronounced, were observed with Rosi for epidydimal and perirenal WAT. The adipocyte number in F3 remained unchanged while in F1 and F2 it decreased particularly in epidydimal and perirenal WAT. It is important to highlight that the observations in F3 animals reveal transgenerational effects (Chamorro-García et al., 2013).

An increase in the offspring weight were also observed after 
exposure to phthalates (diethyl-hexyl-phthalate) $(0.25 \mathrm{mg} / \mathrm{kg}$ b.w.) (Hao et al., 2013) and to BPA (70 $\mu$ g BPA/kg/day) (Somm et al., 2009) in C57BL/6 mice and Sprague-Dawley rats, respectively. Importantly, in the last decades an increase in the medium weight has been observed in several other mammalian species living in the vicinity of human populations, e.g. macaques, chimpanzees, vervet monkeys, marmosets, mice, rats, dogs and cats (Klimentidis et al., 2011). This gives further support to the hypothesis that environmental factors of anthropogenic origin are likely to contribute to human obesity.

\subsection{Interaction with $N R$}

Several EDCs have been reported to interfere with the metabolism through interaction with NRs and the lipid metabolism is no exception (Santos et al., 2012). The NRs present two very conserved domains, the DNA binding domain (DBD) and the ligand biding domain (LBD). The DBD is responsible for the ligation of the NR to the DNA responsive element of target genes, while the LBD accommodate the ligand (Evans and Mangelsdorf, 2014; Mello, 2010; Thornton, 2003). The NRs ligands are very diverse and normally are small hydrophobic molecules. Although the NRs present specific natural ligands, their relation with the recent boom of chemicals seems to be promiscuous (Thornton, 2003). Human and/or mouse PPARs, for example, were reported to interact with several groups of chemicals that include organotins (Harada et al., 2015; Hiromori et al., 2009; Kanayama et al., 2005), several phthalates (Bility et al., 2004; Cocci et al., 2015; Feige et al., 2007; Hurst and Waxman, 2003; Kanayama et al., 2005; Schlezinger et al., 2004) and some pesticides (Kanayama et al., 2005; Takeuchi et al., 2006). Other important NRs implicated in lipid homeostasis have also been reported to be modulated by EDCs, e.g., human FXR by alkylphenols, BPA and a phthalate (Butyl benzyl phthalate (BBzP)) (Kanayama et al., 2005), and LXR $\alpha$ was modulated by alkylphenols and phthalates (Kanayama et al., 2005; Mozzicafreddo et al., 2015).

Metazoans, commonly known as animals, include a wide variety of organisms that can be organized into several groups on the basis of their evolutionary history (see Fig.3) (Jenner, 2007). The key molecular components implicated in lipid metabolism have likely appeared in the ancestor of animals, although for the vast majority of animal lineages functional studies are still missing (Castro et al., 2016; Castro and Santos, 2014). This includes several transcription factors such SREBP and C/EBP, genes coding for metabolic enzymes, for example AcetylCoA Acyltransferase (acaa1) and carnitine palmitoyltransferse (cpt), and the storage of fat as Triacylglycerol (TAG) is also a common feature. When looking into fat storage we find an increasing complexity. Several early branching lineages do not possess a specific organ for fat accumulation, but for example arthropods present an organ with similar liver and adipose tissue functions, called fat body (Birsoy et al., 2013; Lavarías et al., 2009). In vertebrates, liver and adipose tissue are distinct and while in fishes, amphibians and reptiles the adipose tissue is concentrated in intra-abdominal regions, in mammals it is distributed widely in the body. In mammals the hepatic lipid stores are less relevant than in early-branching vertebrates (reviewed by Birsoy et al., 2013). The genomic and physiological evolution occurred in parallel (Brown, 2002). During the course of animal evolution, several duplications waves occurred (e.g. genome duplications in vertebrates), and these have likely contributed to shape the gene repertoire participating in lipid cascades (Brown, 2002; Crow and Wagner, 2006; Lundin, 1999). Within NRs, RXR is present in most metazoans with exception of sponges and some cnidarian species (Sladek, 2011). In contrast, LXR and FXR seem to be deuterostome novelties (Bertrand et al., 2004; Fonseca et al., 2017). Mammals have three PPARs and up to five are observed in teleost genomes (Bertrand et al., 2004; Santos et al., 2012). Outside deuterostomes, PPAR has only been reported in mollusks (Vogeler et al., 2014), though without any functional characterization. The Ecdysone Receptor (ECR), a potential LXR/FXR orthologue (Ollikainen et al., 2006) was thought to be unique of arthropods but has recently been reported in nematodes, mollusks and annelids (Laguerre and Veenstra, 2010). The existence of this diversity of NRs seems to be linked with genome evolution. It appears that although several differences exist in lipid accumulation processes throughout metazoans, several important features are conserved. Therefore, it is not surprising that the obesogen effects are observed in other animal groups beyond mammals (Birsoy et al., 2013; Jordão et al., 2015; Lyssimachou et al., 2015).

This review aims to summarize the available information on the effects of putative obesogens in aquatic organisms. This objective is approached from an evolutionary standpoint, considering the similarities and differences of lipid homeostasis pathways among metazoans. Although aquatic animals are likely to be exposed to several obesogens in their habitat (Lyssimachou et al., 2015), the main focus of previous studies, including recent reviews, has been the modulation of lipid homeostasis by obesogens in mammalian models. However, a growing body of literature indicates that many more metazoan groups in addition to mammals are likely to be affected by this group of chemicals. Here, we review the current knowledge on the field, identifying gaps and highlighting research priorities.

\section{Amphibians}

\subsection{Organotins}

Organotins are persistent organic pollutants, introduced in the environment in 1960s (Antizar-Ladislao, 2008; Maynard, 2002), and were produced for diverse uses from antifouling agents in paints to the textile industry (Antizar-Ladislao, 2008; Bašić et al., 2012; García-Mayor et al., 2012; Maynard, 2002). Although TBT has been banned since 2008 by the European Union, this compound is still widely distributed in marine and freshwater environments (Antizar-Ladislao, 2008; Gipperth, 2009). A recent study in one of the largest harbors in china revealed biological samples with concentrations of organotins ranging from non-detectable up to $826.7 \mu \mathrm{g} / \mathrm{kg}$. Triphenyltin was detected at concentrations of $92.4 \mu \mathrm{g} / \mathrm{kg}$ (Chen et al., 2017).

Organotins have been reported to alter amphibian lipid metabolism. Xenopus laevis when exposed (from stage 48 to metamorphosis) to different concentrations of TBT $(0.33-3.3 \mu \mathrm{g} / \mathrm{L})$ revealed a dose-dependent increase in the formation of ectopic adipocytes in and around the gonads of both sexes. In males exposed to $3.3 \mu \mathrm{g} / \mathrm{L}$ of TBT, the testicular tissue was replaced by adipocytes along the anterior-posterior axis (Grün et al., 2006). Exposure, under the same conditions, to the RXRspecific ligands (10-100 nM of LG100268 and AGN195203) and PPAR $\gamma$ agonist troglitazone $(0.1-1 \mu \mathrm{M})$ resulted in similar alterations, pointing to RXR/PPAR $\gamma$ as the target pathway, which is consistent with the observations in mammalian models (Grün et al., 2006). Despite the lack of alterations in the whole-body weight, the exposure of the wood frog Lithobates sylvaticus from $0.1-5 \mu \mathrm{g} / \mathrm{L}$ TPT from day 3 post-hatching up to 100 days, altered the expression of key lipid metabolic genes of the RXR/PPAR signaling pathway. A decrease in the expression of $r x r \alpha$ and ppara was observed in the animals exposed to both concentrations of TPT after 7 days and a decrease in $l p l$ was observed in the animals exposed just to the lowest concentration. After 100 days, an increase in the expression of genes such as ppara and cyp $4 b 1$ was observed in the animals from both concentrations and an increase of ppary and lpl was observed in the animals from the highest concentration (Higley et al,, 2013). These findings suggest a similar mechanism of action to that described in mammalians, where both TPT and TBT were reported to activate RXR $\alpha$ and PPAR $\gamma$ (Grün et al., 2006; Kanayama et al., 2005).

\subsection{Atrazine}

The herbicide atrazine ((2-chloro)-4-(ethylamino)-6-(isopropylamino)$S$-triazine), a photosynthesis inhibitor commonly detected in the water surface (McCarthy and Fuiman, 2008) also interferes with the lipid 

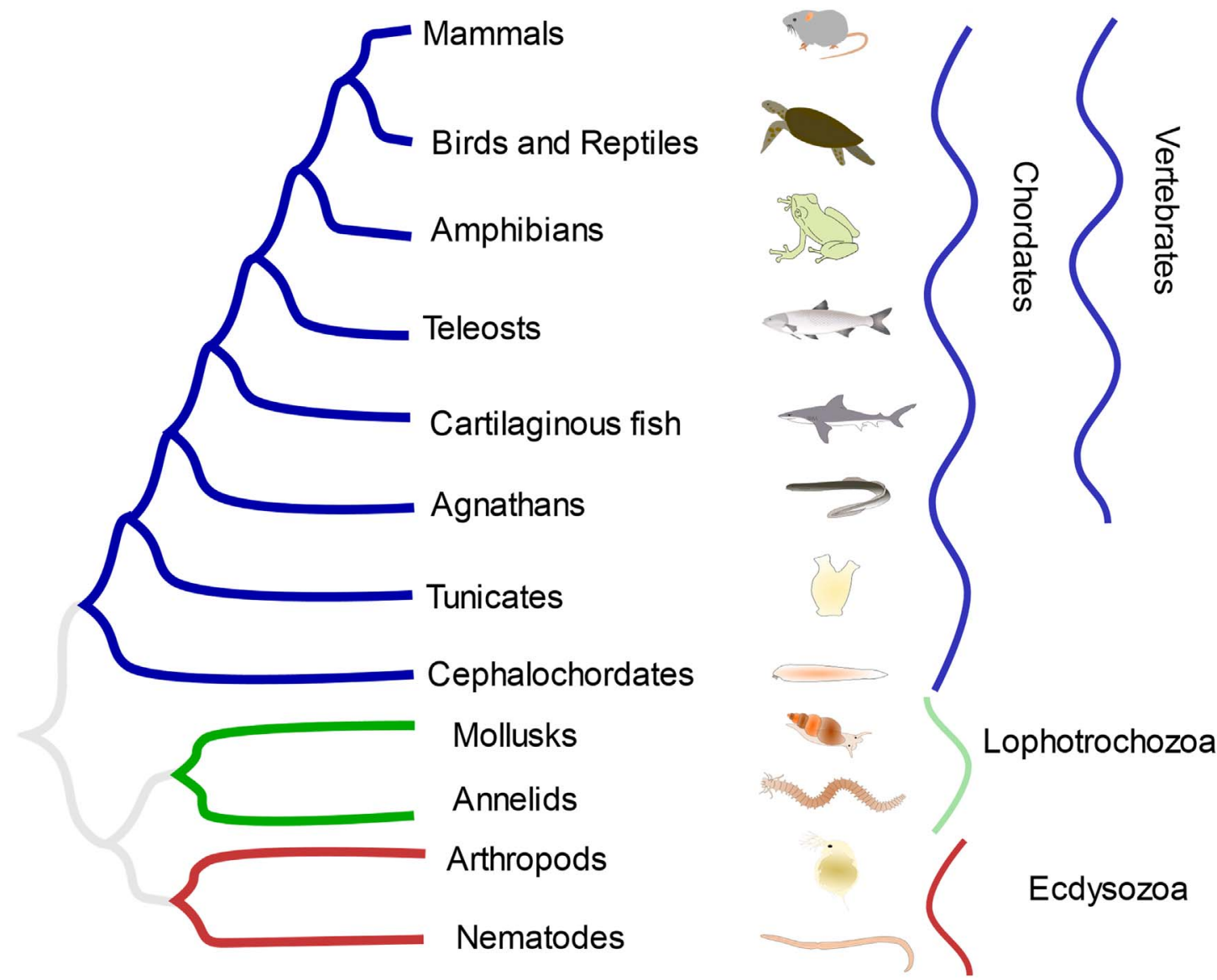

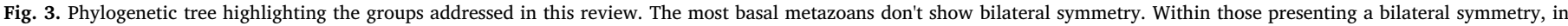

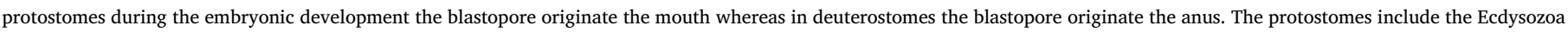

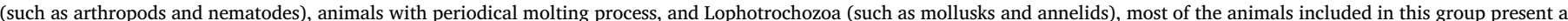
lophophore during some stage of their life cycle. The deuterostomes include Echinodermata, Hemichordata and Chordata (Tunicata, Cephalochordata, Vertebrata) (Jenner, 2007).

metabolism in amphibians. In Texas, near agriculture areas, concentrations of $62.5 \mu \mathrm{g} / \mathrm{L}$ were reported (Pennington et al., 2001), but immediately after application it is commonly detected in puddles at concentrations of $400 \mu \mathrm{g} / \mathrm{L}$ (Zaya et al., 2011a).

Atrazine caused a decrease in the fat body size and in the weight of Xenopus laevis exposed to concentrations close to environmental relevance $(200 \mu \mathrm{g} / \mathrm{L}$ and $400 \mu \mathrm{g} / \mathrm{L}$ ) from stage 47 until stage 66 (or 43 to 62) without observing any alteration in the feeding behaviour (Langerveld et al., 2009; Zaya et al., 2011a, 2011b). The animals exposed to $400 \mu \mathrm{g} / \mathrm{L}$ presented an increase in the transcription of genes involved in lipid catabolism and carbohydrates metabolism and a decrease in the genes involved in lipid storage (Langerveld et al., 2009; Zaya et al., 2011a). These pathways have been reported to be involved with the decrease in fat storage in mammalian. One possible mechanism proposed for the response to atrazine was the down-regulation of glucocorticoid signaling, and an increase in the expression of ppar $\beta$ involved in the utilization of fat (Zaya et al., 2011a). The results observed are in accordance with previous studies in mammalians; lowdoses of atrazine can lead to weight gain through mild mitochondrial damage, while high doses can be toxic and prevent weight gain (Lim et al., 2009).

\subsection{Other compounds}

Different classes of pharmaceuticals are found worldwide in the aquatic ecosystems, with concentrations ranging from the ng/L or $\mu \mathrm{g} / \mathrm{L}$ in urban environments up to the $\mathrm{mg} / \mathrm{L}$ range near input sites (Brodin et al., 2014). A mixture of pharmaceuticals (naproxen, diclofenac, atenolol and gemfibrozil) (100 and $1000 \mu \mathrm{g} / \mathrm{L}$ ) caused a decrease in the hepatic triglycerides levels and an increase in the condition factor (body weight/snout-vent length ${ }^{3} \times 100$ ) of Limnodynastes peronei following 30-days exposure after reaching Gosner developmental stage 26. The triglycerides decrease is probably due to gemfibrozil since this compound is used to regulate cholesterol levels in humans and is known to interact with lipid metabolism (Melvin, 2016).

BPA is a component of polycarbonated plastics widely used in different products like baby bottles, beverage containers and food cans (Bašić et al., 2012). The aquatic contamination with BPA is very variable, the concentrations can vary from non-detected to $17 \mathrm{mg} / \mathrm{L}$ in landfill leachate to $370 \mu \mathrm{g} / \mathrm{L}$ in paper-mill effluents (Fukazawa et al., 2002; Yamamoto et al., 2001; Canesi and Fabbri, 2015; Flint et al., 2012). Although BPA has an obesogenic effect in several species (Guan et al., 2016; Somm et al., 2009), the exposure of Xenopus tropicalis embryos to BPA ( $3.4 \mathrm{mg} / \mathrm{L})$, during 11 weeks, did not alter the ppara and ppary gene expression neither the weight of the animals (MathieuDenoncourt et al., 2015). However, it would be important to evaluate a larger range of concentration since it cannot be discarded the possibility that the lack of effects can be associated with the high concentration tested (see Table 1 ). 
Table 1

Summary of effects of environmental chemicals in amphibian lipid homeostasis (green: up-regulated; red: down-regulated; n.d - not determined; bold-minimum effect concentration).

\begin{tabular}{|c|c|c|c|c|c|c|}
\hline \multirow{2}{*}{ Compound } & \multirow{2}{*}{ Exposure } & \multirow{2}{*}{ Species } & \multicolumn{3}{|c|}{ Endpoints } & \multirow{2}{*}{ Ref. } \\
\hline & & & $\begin{array}{l}\text { Weight/Lipids } \\
\text { alterations }\end{array}$ & Alteration in gene expression & $\begin{array}{l}\text { Biochemical } \\
\text { alterations }\end{array}$ & \\
\hline TBT & $\begin{array}{l}\mathbf{0 . 3 3}-3.3 \mu \mathrm{g} / \mathrm{L} \\
\text { (water); stage } 48 \text { to } \\
\text { metamorphosis; }\end{array}$ & Xenopus laevis & $\begin{array}{l}\text { Formation of } \\
\text { ectopic adipocytes; }\end{array}$ & n.d & n.d & $\begin{array}{l}\text { (Grün et al., } \\
\text { 2006) }\end{array}$ \\
\hline TPT & $\begin{array}{l}\mathbf{0 . 1}-5.0 \mu \mathrm{g} / \mathrm{L} \\
\text { (water); } \\
7 \text { and } 100 \text { days; }\end{array}$ & $\begin{array}{l}\text { Lithobates } \\
\text { sylvaticus }\end{array}$ & $\begin{array}{l}7 \text { days: weight; d } \\
\text { snout-ventral-- } \\
\text { length; }\end{array}$ & $\begin{array}{l}7 \text { days: } r x r \alpha ; \text { ppar } \alpha ; s c d l(5 \mu \mathrm{g} / \mathrm{L}) ; \text { fas } \\
(5 \mu \mathrm{g} / \mathrm{L}) ; \operatorname{lpl}(0.1 \text { and } 5 \mu \mathrm{g} / \mathrm{L}) ; 100 \text { days: } \\
\text { pparo; cyp4b; ppar }(1 \mu \mathrm{g} / \mathrm{L}) \\
\text { fas }(1 \mu \mathrm{g} / \mathrm{L}) ; \operatorname{lpl}(1 \mu \mathrm{g} / \mathrm{L})\end{array}$ & n.d & $\begin{array}{l}\text { (Higley et al., } \\
\text { 2013) }\end{array}$ \\
\hline \multirow{3}{*}{ Atrazine } & $\begin{array}{l}\mathbf{2 0 0 \mu g / L} \text { and } \\
400 \mu \mathrm{g} / \mathrm{L} \text { (water); } \\
\text { Stage } 47-66\end{array}$ & Xenopus laevis & $\begin{array}{l}\text { Fat body size; } \\
\text { Weight; }\end{array}$ & n.d & n.d & $\begin{array}{l}\text { (Zaya et al., } \\
\text { 2011b) }\end{array}$ \\
\hline & 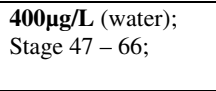 & Xenopus laevis & n.d & $\begin{array}{l}\text { Microarray analysis: } \\
\text { Genes involved in the lipid catabolism; } \\
\text { Genes involved with lipid storage; }\end{array}$ & n.d & $\begin{array}{l}\text { (Zaya et al., } \\
\text { 2011a) }\end{array}$ \\
\hline & $\begin{array}{l}\text { 400ppb (water); } \\
\text { Stage } 43-62\end{array}$ & Xenopus laevis & Fat body size; & $\begin{array}{l}\text { Microarray analysis: } \\
\text { Genes involved with proteolysis, } \\
\text { digestion and carbohydrates metabolism; }\end{array}$ & n.d & $\begin{array}{l}\text { (Langerveld } \\
\text { et al., 2009) }\end{array}$ \\
\hline $\begin{array}{l}\text { Mixture: } \\
\text { naproxen, } \\
\text { diclofenac, } \\
\text { atenolol and } \\
\text { gemfibrozil }\end{array}$ & $\begin{array}{l}\text { 0.1, } 1.0,10,100 \text { and } \\
1000 \mu \mathrm{g} / \mathrm{L} \text { (water); } \\
30 \text { days; }\end{array}$ & $\begin{array}{l}\text { Limnodynastes } \\
\text { peronii }\end{array}$ & $\begin{array}{l}\text { Condition factor; } \\
\text { HSI; }\end{array}$ & n.d & $\begin{array}{l}\text { Hepatic triglycerides } \\
\text { content }(\mathbf{1 0 0} \text { and } \\
1000 \mu \mathrm{g} / \mathrm{L})\end{array}$ & (Melvin, 2016) \\
\hline Compound & $\begin{array}{l}\text { Exposure in } \\
\text { vitro }\end{array}$ & System & Species & Endpoints & & Ref. \\
\hline TBT & $2 \mu \mathrm{g} / \mathrm{L}$ & $\begin{array}{c}\text { Cells-Cos } 7 \\
\text { Luciferase assay; }\end{array}$ & Xenopus laevis & Transactivation $\mathrm{RXR} \alpha$ and $\mathrm{RXR} \gamma$ & & $\begin{array}{l}\text { (Grün et al., } \\
2006)\end{array}$ \\
\hline
\end{tabular}

\section{Teleosts}

\subsection{Organotins}

Alterations in lipid storage are among the effects reported in fishes exposed to TBT. Several species (Oncorhynchus tshawytscha, Danio rerio, Carassius auratus and Sebastiscus marmoratus) when exposed to TBT through water $(1 \mathrm{ng} / \mathrm{L}-16.5 \mu \mathrm{g} / \mathrm{L})$ or diet $(0.4-150 \mathrm{ng} / \mathrm{g} / \mathrm{fish} /$ day) exhibit an increase in lipid and/or TAG content, adiposity (adipocyte size) and/or altered body weight. The alterations reported were observed in short-term (16.5 ng/L-16.5 $\mu \mathrm{g} / \mathrm{L}$ for 1 day) and chronic experiments ( $1 \mathrm{ng} / \mathrm{L}-135 \mathrm{ng} / \mathrm{L}$ during 48 days -9 months) (Lyssimachou et al., 2015; Meador et al., 2011; Ouadah-Boussouf and Babin, 2016; Riu et al., 2014; Tingaud-Sequeira et al., 2011; Zhang et al., 2016; Zhang et al., 2012; Zhang et al., 2013). The effects in the expression pattern of several genes involved in the lipid metabolism, in particular the alterations observed in the nuclear receptors ppary and $r x r$ and their downstream pathways is in line with the hypothesis that TBT alter the lipid metabolism through the interaction with the heterodimer PPAR $\gamma /$ RXR (Lyssimachou et al., 2015; Zhang et al., 2009; Dimastrogiovanni et al., 2015; Li et al., 2014). The impact of TBT in the metabolism of fish seems to be gender and tissue-specific. A different expression pattern of key genes involved in lipid metabolism was observed in liver and brain and in females and males of Danio rerio when exposed to TBT (Lyssimachou et al., 2015).

The alterations in the expression of the NRs rxr and ppar, and their down-stream pathways are in line with the response of mammalian models (Harada et al., 2015; Kanayama et al., 2005; le Maire et al., 2009; Santos et al., 2012). More recently, new evidences suggests that
TBT may impact lipid homeostasis not only through PPAR $\gamma /$ RXR but also through the LXR/RXR heterodimer (Ouadah-Boussouf and Babin, 2016). To clarify this hypothesis the authors measured the TBT-induced adipocity using a fluorescent dye (Nile Red), that allowed to quantify the lipid droplets in zebrafish; this test is known as the zebrafish obesogenic test (ZOT) (Tingaud-Sequeira et al., 2011). This study showed that only the agonists (or antagonists) of PPAR $\beta / \delta$ (GW501516/ GSK3787), PPAR $\gamma$ (rosiglitazone/T0070907), RXR(DHA/UVI3003) and LXR (GW3965/GSK1440233A) could increase (or decrease) the adiposity, indicating that these NRs are the potential targets of TBT. The antagonists of those NRs where then used to rescue the obesogenic response of TBT; the RXR antagonist was fully successful, while the LXR antagonist reverted only partially the TBT effect. The other antagonists failed to rescue the TBT effects. The use of an antagonist of RXR homodimer, that is also an agonist of the heterodimer RXR/PPAR $\gamma$, combined with LXR antagonist and TBT revealed that RXR/PPAR $\gamma$ is also involved in the action of TBT since this mix could not rescue the effect of TBT, but the addition of PPAR $\gamma$ antagonist could decrease the adiposity. Taken together the effects of TBT seem to be mediated through RXR/LXR and/or RXR/PPAR $\gamma$, both permissive heterodimers, which suggests that TBT appears to act through RXR, modulating the downstream pathways to increase the adipocyte number (OuadahBoussouf and Babin, 2016). However, Riu and co-workers did not observe any increase in lipid accumulation in the zebrafish embryos (from $3 \mathrm{dpf}$ to $11 \mathrm{dpf}$ ) exposed to $100 \mathrm{nM}$ and $1 \mu \mathrm{M}$ of Rosi probably because in this early life stage WAT in fish is hardly developed (Flynn et al., 2009; Imrie and Sadler, 2010; Riu et al., 2014). Moreover, $1 \mu \mathrm{M}$ of Rosi failed to transactivate zebrafish PPAR $\gamma$, supporting the hypotheses that the effect of TBT in the heterodimer RXR/PPAR $\gamma$ occurs through RXR (Riu 
et al., 2011). Moreover, it was observed that the cysteine present in the position 285 is essential for the activation of human PPAR $\gamma$ by TBT (Harada et al., 2015) and Danio rerio PPAR $\gamma$ has a tyrosine in the correspondent position (Den Broeder et al., 2015). This substitution in PPAR $\gamma$ of Danio rerio is expected to affect the affinity of TBT to PPAR $\gamma$. Interestingly, this mutation of cysteine 285 is not common to all members of Actinopterygii, since Sparus aurata and Pleuronectes platessa, for example, have a cysteine molecule in the homologous position (Leaver et al., 2005).

\subsection{BPA and BPA analogues}

BPA and BPA analogues are ubiquitous chemicals detected in the environment. (Fukazawa et al., 2002; Yamamoto et al., 2001). Moreover, recent data suggests that this group of chemicals is able to impact lipid homeostasis (Birceanu et al., 2015; Riu et al., 2014, 2011). The reported effects of BPA and BPA analogues include increase in lipid accumulation and body mass in Danio rerio when exposed to Tetrabromobisphenol A (TBBPA) (5.5 and $55 \mu \mathrm{g} / \mathrm{L}$ ) or tetrachlorobisphenol A (TCBPA) $(37 \mu \mathrm{g} / \mathrm{L})$ during 19 days, and in Sparus aurata when exposed to BPA ( $50 \mathrm{mg} / \mathrm{kg} \mathrm{bw}$ ) during 21 days, (Maradonna et al., 2015; Riu et al., 2014, 2011). However, in Gobiocypris rarus females a decrease in serum TGA content was observed under BPA $(15 \mu \mathrm{g} / \mathrm{L})$ exposure (Guan et al., 2016). Although the transcription patterns of several genes involved in lipid metabolism were altered in Sparus aurata (exposed to $50 \mathrm{mg} / \mathrm{kg}$ bw of BPA) and in Gobiocypris rarus (exposed to $15 \mu \mathrm{g} / \mathrm{L} \mathrm{BPA}$ ), the pattern of expression is not the same; the fasn gene appeared up-regulated in Sparus aurata and down-regulated in Gobiocypris rarus males (Guan et al., 2016; Maradonna et al., 2015). The NRs reported to be involved in the lipid homeostasis (PPAR $\alpha, \beta, \gamma$ and RXR) and lpl genes were up-regulated while hormone sensitive lipase ( $h s l$ ) gene was down-regulated in Sparus aurata which is consistent with the lipid accumulation observed (Maradonna et al., 2015). In Gobiocypris rarus the decrease of fasn, acetyl-CoA carboxylase 1 (acaca) and acetylCoA carboxylase 2 ( $a c a c b)$ expression is not consistent with the respective enzymatic activity, but carnitine palmitoyltransferase $1 \mathrm{~A}$ (cptIa) expression and enzymatic activity is increased in males and decreased in females (Guan et al., 2016). The disparity between gene expression and enzymatic activity can be associated with several regulatory processes (Vogel and Marcotte, 2012). The effect of BPA in lipid homeostasis of Gobiocypris rarus suggests a gender-specific effect since the activity of CPT1 is increased in males, but decreased in females similar to cptIa gene expression. The observed increase in the TAG content in females serum and the tendency for decrease in males is consistent with the previous observations (Maradonna et al., 2015). One possible explanation for the differences in Sparus aurata and Gobiocypris rarus studies described above can be gender related given that in the Sparus aurata study genders of the specimens were not discriminated (Guan et al., 2016; Maradonna et al., 2015).

One possible mechanism for the action of BPA analogues in the lipid metabolism is the modulation of PPAR $\gamma$. Riu et al. (2011) observed that BPA analogues, $10 \mu \mathrm{M}$ TBBPA and $10 \mu \mathrm{M}$ TCBPA, are able of in vitro transactivating zebrafish PPAR $\gamma$ with a similar affinity to that observed in human PPAR $\gamma$ (Riu et al., 2011). An alternative hypothesis involves estrogenic pathways (García-Mayor et al., 2012), as BPA has the potential to bind and activate the estrogen receptor (ER), and interact with a variety of other targets in mammalian cells, including thyroid hormone receptors (Bašić et al., 2012; Bonefeld-Jørgensen et al., 2007). Further research is needed to fully understand the underlying mechanisms.

\subsection{Alkylphenols}

Alkylphenols are commonly used in industrial and consumer products (Pereira-Fernandes et al., 2013). Concentrations between 1.1 and $1347 \mu \mathrm{g} / \mathrm{kg}$ of nonylphenol (NP) and $0.73-54.4 \mu \mathrm{g} / \mathrm{kg}$ of octylphenol (tOP) were detected in mussels and 5-60.5 $\mu \mathrm{g} / \mathrm{kg}$ of NP and $0.2-31.4 \mu \mathrm{g} /$ $\mathrm{kg}$ in fish tissues (David et al., 2009). The Exposure of Sparus aurata to high levels of NP $(50 \mathrm{mg} / \mathrm{kg}$ bw) or t-OP $(5 \mathrm{mg} / \mathrm{kg}$ bw and $50 \mathrm{mg} / \mathrm{kg}$ bw) caused an increase in the number of specimens with severe lipid accumulation in the liver, more pronounced in the t-OP groups. The transcription patterns of several genes involved in lipid metabolism (i.e. ppara, ppar $\beta$, ppar, rxr, fasn, $l p l$ and $h s l$ ) were also increased, emphasizing the effect of NP and t-OP in the lipid metabolism (Maradonna et al., 2015). It would be interesting in future studies to test the effects of lower NP and t-OP levels.

Alkylphenols, such as NP and t-OP, have been reported to activate the human Estrogen Receptor (ER) and several evidences point to the possible involvement of ER in the action of certain obesogens, thus explaining the results observed (Bonefeld-Jørgensen et al., 2007; Kramarova et al., 2009; Yang et al., 2015).

\subsection{Phthalates}

Phthalates are synthetic organic compounds derived from phthalic acid. These compounds are used since the 1930s as plasticizing agents in cosmetics, paints and medicines and were found in the aquatic environment in concentrations as high as $98 \mu \mathrm{g} / \mathrm{L}$ (Fromme et al., 2002). Recent evidences shows that these compounds also target the lipid metabolism of fish (García-Mayor et al., 2012; Grün and Blumberg, 2009b, 2007; Pereira-Fernandes et al., 2013). Phthalates were reported to increase the transcription of NR involved in lipid metabolism (ppaar $\alpha$, ppar $\beta$ and ppary) in zebrafish exposed to $39 \mu \mathrm{g} / \mathrm{L}$ DEHP and $1.7 \mu \mathrm{g} / \mathrm{L}-1.7 \mathrm{mg} / \mathrm{L}$ phthalic acid (PA) (Maradonna et al., 2013). In Sparus aurata, exposure to diisodecyl phthalate (DiDP) (45.1-450.7 $7 \mathrm{~g}$ / L) not only up regulated the expression of ppars and $r x r$, but also the expression of some downstream genes, cptIa, cptIb, fatty acid desaturase 2 (fads2), stearoyl-CoA desaturase 1A (scd1a), scd1, lpl, hepatic lipase $(\mathrm{hl})$, fatty acid binding protein ( $f a b p)$, apolipoprotein A-I (apoa-1) and srebp) (Cocci et al., 2015). In zebrafish exposed to $5000 \mathrm{mg} / \mathrm{kg}$ di-2ethylhexylphthalate (DEHP), during 10 days, no changes were observed in the expression of the downstream genes of the PPARs signaling pathways (acox and lpl) in the liver, although the hepatosomatic index was increased. The observed alteration in the hepatosomatic index could be associated with increase fat accumulation or as a toxic response to DEHP (Fabbrini et al., 2010; Milić et al., 2014; Sadekarpawar and Parikh, 2013; Uren-Webster et al., 2010). Taken together, the data suggest that the interaction of phthalates with the lipid metabolism may occur through PPARs modulation. DiDPis can bind to Sparus aurata PPAR $\alpha$ and $\gamma$ with similar affinity as to the human PPARs, MEHP can transactivate zebrafish PPAR $\gamma$ and the relation between the interaction of phthalates with PPARs and their obesogenic effect was previously established for mammalians (Cocci et al., 2015; Desvergne et al., 2006; Maradonna et al., 2013; Riu et al., 2014).

\subsection{Organophosphates}

Some organophosphates, such as Fenitrothion and Trichlorfon, are pesticides that have been used extensively in agriculture and can enter the freshwater environments (McCarthy and Fuiman, 2008; Sancho et al., 2009; $\mathrm{Xu}$ et al., 2012). Xu and co-workers described an increase in the liver TAG content in the Carassius auratus gibelio exposed to trichlorfon $(1.0-4.0 \mathrm{mg} / \mathrm{L})$ for 30 days (Xu et al., 2012). However, Sancho and co-workers reported a 
decrease in liver total lipid content in Anguilla anguilla after a short-term exposure ( 2 and $96 \mathrm{~h}$ ) to fenitrothion $(0.4 \mathrm{mg} / \mathrm{L}$ ) (Sancho et al., 1998). The mechanism of action of these compounds in lipid metabolism remains to be elucidated, but similar effects were already reported in mammalians (Meggs and Brewer, 2007).

\subsection{Fibrates}

Fibrates are commonly used to control hypercholesterolemia in humans. Given their widespread use, they are frequently detected in the freshwater environment (Velasco-Santamaría et al., 2011). One of the first fibrates to be reported in water samples was clofibric acid (CA), an active and persistent metabolite of clofibrate, a blood lipid lowering agent (Emblidge and DeLorenzo, 2006; Runnalls et al., 2007). Clofibrate was detected in surface water at concentrations of 6-7 $\mu \mathrm{g} / \mathrm{L}$, fenofibrate and gemfibrozil were detected in much lower concentrations $(\approx 0.05 \mu \mathrm{g} / \mathrm{L}$ ) (Corcoran et al., 2010). Several studies demonstrated the capacity of these compounds to interact with the lipid metabolism in non-mammalian animal models. A decrease in the weight of mosquito fish (Gambusia holbrooki) males when exposed to clofibrate (18.4 to $295 \mathrm{mg} / \mathrm{L})$ and an increase in females exposed to CA $(4.03 \mathrm{mg} / \mathrm{L})$ during 28 days have been reported (Nunes et al., 2004). In contrast, an exposure to CA at $10 \mu \mathrm{g} / \mathrm{L}$ for 10 days did not alter the levels of lipids and cholesterol in the fish Fundulus heteroclitus (Emblidge and DeLorenzo, 2006).

A multigenerational study using zebrafish revealed very informative results on the effect of CA. F0 generation was exposed to $1 \mathrm{mg} / \mathrm{g}$ and $10 \mathrm{mg} / \mathrm{g}$ CA through the diet and the offspring (F1) were raised with control diet. A decrease in the weight and muscle triglyceride levels was observed in $\mathrm{F} 0$, but $\mathrm{F} 1$ presented an increase in weight in the offsprings of the highest exposure group. The gene expression pattern for both generations was also different. In male livers of the F0, the expression of ppar $\alpha$ and acox 1 increased in the animals exposed to the highest concentration, and in F1 although the expression of ppary increased, the expression of apoa-1 and ppar $\beta 1$ decreased. This study reveals an opposite pattern of response in the descendants when compared with the parent generation (Coimbra et al., 2015). ppara expression also increased in Cyprinus carpio exposed to $20 \mathrm{mg} / \mathrm{L}$ of CA during 4 days and acox 1 expression increased not only in the animals exposed to $20 \mathrm{mg} / \mathrm{L}$ but also in the animals exposed at a lower concentration $(4 \mu \mathrm{g} / \mathrm{L})$. These responses are in line with the ones observed in zebrafish. The expression of other genes, such as Acetyl-CoA Acyltransferase 1 (acaa1), cytochrome P450 4 (cyp4), sterol 27-hydroxylase (cyp27a), apoA1, lpl and superoxide dismutase (sod1) also increased in one or both CA exposures. These observations support the evidence that these compounds interfere with the lipid metabolism not only in mammals but also in the Actinopterygii group (Corcoran et al., 2015).

The effects of other fibrates, besides CA and clofibrate, have also been reported. A decrease in plasma cholesterol levels was found in zebrafish exposed to 1.7, 33 and $70 \mathrm{mg}$ bezafibrate (BZF)/g food after 2 and 7 days of exposure, along with a decrease in the expression of ppar $\beta$ and ppary after 2 days of exposure and an increase in the expression of ppar $\beta$ and Steroidogenic Acute Regulatory Protein (star) after 21 days of exposure (Velasco-Santamaría et al., 2011). The exposure of rainbow trout (Oncorhychus mykiss) to $100 \mathrm{mg}$ of Gemfibrozil/kg during 15 days increased the relative cholesterol levels and caused a decrease in the relative TAG levels and the phospholipids/triacylglycerol ratio. Lpl gene expression was increased, but no alteration was observed in the ppars genes (Prindiville et al., 2011). These results seem to be in line with data from mammalian models, as fibrates are known PPAR a agonists and this NR is associated with fatty acid uptake and oxidation (Coimbra et al., 2015). In contrast to most studies reported in this review, fibrates mostly led to the depletion of lipid tissue levels.

\subsection{Other compounds}

Besides the classes of compounds highlighted above, other compounds have also been reported to interfere with fish lipid metabolism (Zhu et al., 2014). One example is the herbicide atrazine $(0.17 \mathrm{mg} / \mathrm{L})$ that caused an increase in hepatic lipid levels in the grey mullet (Liza ramada) after an exposure of 21 days (Biagianti-Risbourg and Bastide, 1995). Another example is DDT, a pesticide and well documented persistent organic pollutant (Lyche et al., 2013). Zebrafish exposed to $0.1 \mu \mathrm{g} / \mathrm{L}$ and $1 \mu \mathrm{g} / \mathrm{L}$ of DDT during 60 days displayed an increase in the saturated long chain fatty acids C16:0 and C18:0 along with monounsaturated C18:1n9 accompanied with a decrease of the levels of polyunsaturated fatty acids $\mathrm{C} 20: 3 \mathrm{n} 3, \mathrm{C} 20: 4 \mathrm{n} 6$, and C22:6n 3 in a DDTconcentration-dependent manner. A decrease in the weight of the females was also observed for the concentration of $0.1 \mu \mathrm{g} / \mathrm{L}$ DDT (Zhong et al., 2012).

\subsection{Environmental mixtures}

In the environment compounds are not present alone but in complex mixtures. In a study aiming to evaluate the effects of these complex mixtures, zebrafish was exposed through the diet from day 6 until 5 months post-fertilization to two different mixtures of organic pollutants extracted from fish liver of Lota lota, originated from two different lakes in Norway (Lake Mjøsa and Lake Losna). An increase in weight and alterations in the expression of genes related to lipid metabolism were observed. An Ingenuity Pathway Analysis (IPA) established a relationship between the affected genes and PPAR $\gamma, E R \alpha$ and Hepatocyte Nuclear Factor 4 A (HNF4A), suggesting that these NRs are the key regulators of the genes affected (Lyche et al., 2011; NourizadehLillabadi et al., 2009). The decedents of F1 were also exposed to the mixtures and presented a decrease in weight and length (Berg et al., 2011). The 3rd generation embryos (4, 7.5, 12 and $24 \mathrm{hpf}$ ) also presented alterations in the transcription pattern of the genes related with lipid metabolism (Lyche et al., 2013).

Several additional studies show evidences of changes in lipid homeostasis associated with chemical exposure in the field. Accumulation of lipid droplets and an increase in the ppary and rxra transcription levels was observed in the liver of Atlantic Bluefin tuna (Thunnus thynnus) associated with levels of dioxin-like PCBs above the safe limits established by the European commission regulation (EU $\mathrm{n}$. 1259/2011 of 02.12.2011) (Maisano et al., 2015). In Tilapia guineensis, Sarotherodon galileaus and Oreochromis niloticus a correlation between the concentrations of Polycyclic aromatic hydrocarbons (PAHs) and PCBs and the increase of gene transcription of ppars ( $\alpha, \beta$ and $\gamma$ ) was also observed (Adeogun et al., 2016b). Sarotherodon melanotheron from two sites in Nigeria with different contamination levels showed alterations in the liver somatic index (LSI), kidney somatic index (KSI) and expression of the genes ppar $\alpha, \beta$ and $\gamma$. The increase in LSI and in gene transcription was observed in a concentration dependent manner (Adeogun et al., 2016a).

Taking these studies together, it becomes evident that some EDCs can affect fish lipid homeostasis, even though only the sub-class teleost was analyzed here. An important remark that should be considered in future studies concerns gender differences; in some studies, males and females show different responses, highlighting the importance of analysing the response in both genders (See Table 2). 
Table 2

Summary of effects of environmental chemicals in fish lipid homeostasis (green: up-regulated; red: down-regulated; n.d - not determined; bold-minimum effect concentration).

\begin{tabular}{|c|c|c|c|c|c|c|}
\hline \multirow[t]{2}{*}{ Compound } & \multirow[t]{2}{*}{ Exposure in vivo } & \multirow[t]{2}{*}{ Species } & \multicolumn{3}{|c|}{ Endpoints } & \multirow[t]{2}{*}{ Ref. } \\
\hline & & & $\begin{array}{l}\text { Weight/Lipids } \\
\text { alterations }\end{array}$ & $\begin{array}{l}\text { Alteration in gene } \\
\text { expression }\end{array}$ & $\begin{array}{l}\text { Biochemical } \\
\text { alterations }\end{array}$ & \\
\hline \multirow{9}{*}{ TBT } & $\begin{array}{l}2.8 \text { ng/g and } 150 \\
\text { ng/g (diet); } \\
62 \text { days; }\end{array}$ & $\begin{array}{l}\text { Oncorhynchus } \\
\text { tshawytscha }\end{array}$ & Total lipid content; & n.d & n.d & (Meador et al., 2011) \\
\hline & 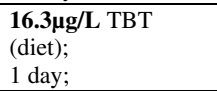 & Danio rerio & Adiposity; & n.d & n.d & $\begin{array}{l}\text { (Tingaud-Sequeira et } \\
\text { al., 2011) }\end{array}$ \\
\hline & $\begin{array}{l}27.4-137.10 \mathrm{ng} / \mathrm{L} \\
\text { (water); } \\
9 \text { months; }\end{array}$ & Danio rerio & $\begin{array}{l}\text { Male weight. } \\
\text { Male CF ( } 27.4 \text { ng/L); } \\
\text { Females CF; } \\
\text { Female LSI; }\end{array}$ & 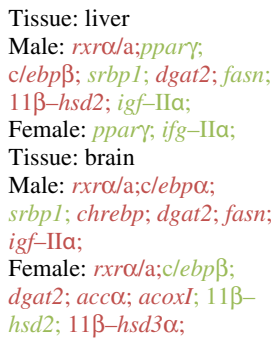 & Male hepatic triglyceride; & $\begin{array}{l}\text { (Lyssimachou et al., } \\
\text { 2015) }\end{array}$ \\
\hline & $\begin{array}{l}\mathbf{2 . 4 4} \mathbf{n g} / \mathrm{L} \text { and } 24.4 \\
\text { ng/L (water); } \\
54 \text { days; }\end{array}$ & Carassius auratus & $\begin{array}{l}\text { Body weight; } \\
\text { Food intake (only for } \\
2.44 \mathrm{ng} / \mathrm{L} \text { ); }\end{array}$ & n.d & $\begin{array}{l}\text { Metabolic rate indicators } \\
\text { (only for } 2.44 \mathrm{ng} / \mathrm{L} \text { ); }\end{array}$ & (Zhang et al., 2016) \\
\hline & $\begin{array}{l}\mathbf{0 , 7 5} \boldsymbol{\mu g} / \mathbf{L} \text { and } 7,5 \\
\mu \mathrm{g} / \mathrm{L} \text { (water); } \\
60 \text { days; }\end{array}$ & Cyprinus carpio & n.d & n.d & $\begin{array}{l}\text { Enzymes activity: trypsin, } \\
\text { lipase and amylase; }\end{array}$ & (Li et al., 2014) \\
\hline & $\begin{array}{l}0.1 \mathrm{ng} / \mathrm{L} ; 10 \mathrm{ng} / \mathrm{L} ; \\
\mathbf{1 0 0 n g / L ;} \\
48 \text { days; }\end{array}$ & $\begin{array}{l}\text { Sebastiscus } \\
\text { marmoratus } \\
\text { (females) }\end{array}$ & $\begin{array}{l}\text { Tissue: Ovaries; } \\
\text { Total lipid (100ng/L); }\end{array}$ & n.d & n.d & (Zhang et al., 2013) \\
\hline & $\begin{array}{l}2.7, \mathbf{2 7 . 4}, 274 \mathrm{ng} / \mathrm{L} \\
\text { (water); } \\
48 \text { days; }\end{array}$ & $\begin{array}{l}\text { Sebastiscus } \\
\text { marmoratus }\end{array}$ & $\begin{array}{l}\text { Total lipid content in } \\
\text { testes }(\mathbf{2 7 4 n g / L})\end{array}$ & $\begin{array}{l}\text { Tissue: Testes } \\
\operatorname{rxr} \beta(\mathbf{2 7 . 4} \text { and } 274 \mathrm{ng} \\
\mathrm{Sn} / \mathrm{L}), \operatorname{rx} \gamma, \operatorname{ppar} \gamma\end{array}$ & n.d & (Zhang et al., 2009) \\
\hline & $\begin{array}{l}3.25,16.3, \mathbf{1 6 3 n g} / \mathrm{L} \text {, } \\
1.63 \text { and } 16.3 \mu \mathrm{g} / \mathrm{L} \\
\text { (water); } 1 \text { day; }\end{array}$ & Danio rerio & $\begin{array}{l}\text { Adiposity in } \\
\text { starvation }(163 \mathrm{ng} / \mathrm{L} \text {, } \\
1.63 \text { and } 16.3 \mu \mathrm{g} / \mathrm{L})\end{array}$ & n.d & n.d & $\begin{array}{l}\text { (Ouadah-Boussouf } \\
\text { and Babin, 2016) }\end{array}$ \\
\hline & $\begin{array}{l}\text { 325.5ng/L(water); } \\
3 \mathrm{dpf}-11 \mathrm{dpf} \text {, } \\
\text { followed by } 19 \text { days } \\
\text { without TBT; }\end{array}$ & Danio rerio & Body mass index; & n.d & n.d & (Riu et al., 2014) \\
\hline TBBPA & $\begin{array}{l}\mathbf{5 . 5}-55 \mu \mathrm{g} / \mathrm{L} \text { (water); } \\
3 \mathrm{dpf}-11 \mathrm{dpf} \text {, } \\
\text { followed by } 19 \text { days } \\
\text { without TBT; }\end{array}$ & Danio rerio & Body mass index; & n.d & n.d & (Riu et al., 2014) \\
\hline TCBPA & $\begin{array}{l}37 \mu \mathrm{g} / \mathrm{L} \text { (water); } \\
3 \mathrm{dpf}-11 \mathrm{dpf}, \\
\text { followed by } 19 \text { days } \\
\text { without TBT; }\end{array}$ & Danio rerio & Body mass index; & n.d & n.d & \\
\hline \multirow[t]{2}{*}{ BPA } & 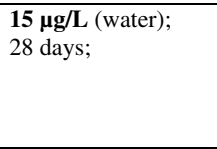 & Gobiocypris rarus & n.d & $\begin{array}{l}\text { Females: acaca; acacb; } \\
\text { gpat1; } \\
\text { Males: fasn; gpat1; cptIo; }\end{array}$ & $\begin{array}{l}\text { Serum triglyceride content } \\
\text { (females); } \\
\text { Enzyme activity: FASN, } \\
\text { ACC, CPTI (female); CPTI } \\
\text { (males); GPAT (males); }\end{array}$ & (Guan et al., 2016) \\
\hline & \multirow{2}{*}{$\begin{array}{l}\mathbf{5 m g} / \mathbf{K g}(1) \text { bw and } \\
50 \mathrm{mg} / \mathrm{Kg}(2) \text { bw } \\
\text { (diet); } \\
21 \text { days; }\end{array}$} & \multirow[t]{2}{*}{ Sparus aurata } & \multirow{2}{*}{$\begin{array}{l}\text { Liver: Lipid (1, t- } \\
\text { OP1 and 2, BPA1); } \\
\text { Food intake; }\end{array}$} & \multirow{2}{*}{$\begin{array}{l}\text { lpl; hsl; pparo; ppar } \beta \\
\text { ppar } ; \text { rxr }(\text { except t-OP); } \\
\text { fas; }\end{array}$} & \multirow[t]{2}{*}{ n.d } & \multirow[t]{2}{*}{$\begin{array}{l}\text { (Maradonna et al., } \\
\text { 2015) }\end{array}$} \\
\hline $\mathrm{t}-\mathrm{OP}$ & & & & & & \\
\hline DEHP & $\begin{array}{l}\mathbf{0 . 5}-5000 \mathrm{mg} / \mathrm{Kg} \\
\text { (injection); } \\
10 \text { days; } \\
\end{array}$ & Danio rerio (males) & HIS (5000 mg/Kg); & $\begin{array}{l}\text { Tissue: testis } \\
\text { acoxl; }\end{array}$ & n.d & $\begin{array}{l}\text { (Uren-Webster et al., } \\
\text { 2010) }\end{array}$ \\
\hline trichlorfon & $\begin{array}{l}\mathbf{1 . 0}-4.0 \mathrm{mg} / \mathrm{L} \\
\text { (water); } \\
30 \text { days; }\end{array}$ & $\begin{array}{l}\text { Carassius auratus } \\
\text { gibelio }\end{array}$ & n.d & n.d & $\begin{array}{l}\text { Triglyceride content in the } \\
\text { liver; }\end{array}$ & (Xu et al., 2012) \\
\hline fenitrothion & $\begin{array}{l}\text { 0.4mg/L (water); } \\
2-96 \text { hours; }\end{array}$ & Anguilla Anguilla & $\begin{array}{l}\text { Lipid content in } \\
\text { liver; }\end{array}$ & n.d & n.d & (Sancho et al., 1998) \\
\hline clofibrate & $\begin{array}{l}\text { 18.4, } 37.9,73.8, \\
147.5 \text { and } 295 \mu \mathrm{g} 1^{-1} \\
\text { (water); } 28 \text { days; }\end{array}$ & $\begin{array}{l}\text { Gambusia } \\
\text { holbrooki }\end{array}$ & Male weight; & n.d & n.d & (Nunes et al., 2004) \\
\hline
\end{tabular}




\begin{tabular}{|c|c|c|c|c|c|c|}
\hline \multirow{3}{*}{ Clofibric acid } & $\begin{array}{l}\text { F0 - } 1 \text { mg/gand } 10 \\
\text { mg/g(diet); } \\
\text { F1 - control diet; }\end{array}$ & Danio rerio & $\begin{array}{l}\text { Weight (F0); } \\
\text { Triglyceride levels } \\
\text { (muscle ofmale } \\
\text { fish); } \\
\text { Weight (F1) } \\
\text { (10mg/g); }\end{array}$ & $\begin{array}{l}\text { F0: pparo; acox } 1 ; \\
\text { F1: ppar } \gamma \text {; apoal; ppar } \beta 1 ;\end{array}$ & n.d & (Coimbra et al., 2015) \\
\hline & $\begin{array}{l}4 \mu \mathrm{g} / \mathrm{L} \text { (water); } \\
4 \text { and } 10 \text { days; }\end{array}$ & \multirow[t]{2}{*}{ Cyprinus carpio } & \multirow[t]{2}{*}{ n.d } & $\begin{array}{l}\text { Tissue: liver } \\
\text { acox } 1 ; \text { cyp } 4 ; \operatorname{lpl} \\
\text { acaa } 1 ; \text { apoA } 1 ; \operatorname{cyp} 27 a \\
\text { (only } 10 \text { days) }\end{array}$ & $\begin{array}{l}\text { ACOX } \\
\text { activity; (only } 10 \text { days) }\end{array}$ & \multirow[t]{2}{*}{ (Corcoran et al., 2015) } \\
\hline & $\begin{array}{l}\mathbf{2 0 m g} / \mathbf{L} \text { (water); } \\
4 \text { and } 10 \text { days; }\end{array}$ & & & $\begin{array}{l}\text { Tissue: liver } \\
\text { acox } 1 ; \operatorname{cyp} 27 a ; \\
\text { pparo: (only } 4 \text { days) } \\
\text { apoal; sod1; }\end{array}$ & ACOX activity; & \\
\hline BZF & $\begin{array}{l}\mathbf{1 . 7}, 33 \text { and } 70 \mathrm{mg} / \mathrm{g} \\
\text { (diet); } \\
2,7 \text { and } 21 \text { days; }\end{array}$ & Danio rerio (male) & n.d & $\begin{array}{l}\text { 2days: } \text { ppar } \beta ; \text { ppar } \gamma \\
\text { 21days: ppar } \beta \text {; star; } \\
\text { cyp } 17 \text { a1; }\end{array}$ & $\begin{array}{l}\text { Plasma cholesterol levels } \\
\text { ( } 7 \text { and } 21 \text { days); }\end{array}$ & $\begin{array}{l}\text { (Velasco-Santamaría } \\
\text { et al., 2011) }\end{array}$ \\
\hline Gemfibrozil & $\begin{array}{l}\mathbf{1 0 0} \mathbf{~ m g} / \mathbf{K g} \\
\text { (injection); } \\
15 \text { days; }\end{array}$ & $\begin{array}{l}\text { Oncorhychus } \\
\text { mykiss (female) }\end{array}$ & n.d & $l p l$ & $\begin{array}{l}\text { Relative cholesterol levels; } \\
\text { Relative triacylglycerol } \\
\text { levels; Ratio of } \\
\text { phospholipids/triacylglycerol; }\end{array}$ & $\begin{array}{l}\text { (Prindiville et al., } \\
\text { 2011) }\end{array}$ \\
\hline Atrazine & $\begin{array}{l}\mathbf{0 . 1 7} \mathbf{~ m g / L} \text { (water); } \\
21 \text { days; }\end{array}$ & Liza ramada & $\begin{array}{l}\text { Lipid accumulation } \\
\text { in the liver. }\end{array}$ & n.d & n.d & $\begin{array}{l}\text { (Biagianti-Risbourg } \\
\text { and Bastide, 1995) }\end{array}$ \\
\hline DDT & $\begin{array}{l}\mathbf{0 . 1} \mu \mathrm{g} / \mathrm{L} \text { and } 1 \mu \mathrm{g} / \mathrm{L} \\
\text { (water); } \\
60 \text { days; }\end{array}$ & Danio rerio & $\begin{array}{l}\text { Weight of the } \\
\text { females }(0.1 \mu \mathrm{g} / \mathrm{L}) \text {; }\end{array}$ & n.d & $\begin{array}{l}\text { Saturate long chain fatty } \\
\text { acids (C16:0 and C18:0), in } \\
\text { monounsaturated long chain } \\
\text { fatty acid (C18:1n9); } \\
\text { Polyunsaturated fatty acids) } \\
\text { C20:3n3, C20:4n6, and } \\
\text { C22:6n3); }\end{array}$ & (Zhong et al., 2012) \\
\hline PFNA & $\begin{array}{l}\text { 0.01, } 0.1 \text {, and } 1.0 \\
\text { mg/L(water); } \\
\text { 180days; }\end{array}$ & Danio rerio & $\begin{array}{l}\text { Weight; } \\
\text { Length; } \\
\text { HIS }(0.01 \text { and } 0.1 \\
\text { mg/L); }\end{array}$ & $\begin{array}{l}\text { Males: } \\
\text { fabps; pparoa; pparob; } \\
\text { ppary; ppar } \beta a ; \text { ppar } \beta b ; \\
\text { clebps; } \\
\text { Females: } \\
\text { fabps; pparoa; pparob; } \\
\text { ppary; ppar } \beta a ; \text { ppar } \beta b ; \\
\text { clebps; }\end{array}$ & $\begin{array}{l}\text { Tissue: liver } \\
\text { Total cholesterol level (0.1 } \\
\text { and } 1.0 \mathrm{mg} / \mathrm{L}) \text {; } \\
\text { Triglyceride content (male); } \\
\text { Triglyceride content } \\
\text { (female); }\end{array}$ & (Zhang et al., 2012) \\
\hline Compound & Exposure in vitro & System & Species & \multicolumn{2}{|l|}{ Endpoints } & Ref. \\
\hline TBT & 32.6 $\mu \mathrm{g} / \mathrm{L}$ & \multirow{5}{*}{$\begin{array}{l}\text { Liver cell line } \\
\text { (RTL-W1) }\end{array}$} & \multirow[t]{5}{*}{ Rainbow trout } & \multicolumn{2}{|l|}{ Genes: abcal; lpl; fas } & \multirow{5}{*}{$\begin{array}{l}\text { (Dimastrogiovanni } \\
\text { et al., 2015) }\end{array}$} \\
\hline TPT & $36.8 \mu \mathrm{g} / \mathrm{L}$ & & & \multicolumn{2}{|c|}{$\begin{array}{l}\text { Genes: abcal; fatp I; fas; lxr; } \\
\text { Lipids: TAG; }\end{array}$} & \\
\hline $4-\mathrm{NP}$ & 4.4mg/L; & & & \multicolumn{2}{|c|}{$\begin{array}{l}\text { Genes: abcal; cd } 36 ; \text { lpl; fas; ppar } \beta \text {; } \\
\text { Lipids: TAG; }\end{array}$} & \\
\hline DEHP & $1.9 \mathrm{mg} / \mathrm{L}$ & & & \multicolumn{2}{|c|}{$\begin{array}{l}\text { Genes: } c d 36 ; l p l ; \text { fas; } \\
\text { Lipids: TAG; }\end{array}$} & \\
\hline BPA & $2.28 \mathrm{mg} / \mathrm{L}$ & & & \multicolumn{2}{|c|}{$\begin{array}{l}\text { Genes: abcal; cd36; fatp 1; lpl; fas; lxr; pparo; ppar } \beta \text {; } \\
\text { Lipids: TAG; }\end{array}$} & \\
\hline TBBPA & $5.44 \mathrm{mg} / \mathrm{L}$ & \multirow{2}{*}{$\begin{array}{l}\text { HGELN human cell } \\
\text { line; } \\
\text { (transfected with } \\
\text { PPAR } \gamma \text { ) }\end{array}$} & \multirow[t]{2}{*}{ Danio rerio } & \multirow{2}{*}{\multicolumn{2}{|c|}{ Transactivation; }} & \multirow[t]{2}{*}{ (Riu et al., 2011) } \\
\hline TCBPA & $3.66 \mathrm{mg} / \mathrm{L}$ & & & & & \\
\hline DEHP & $\begin{array}{l}19.53 \mathrm{ng} / \mathrm{L}-39 \mu \mathrm{g} / \mathrm{L} \\
4 \text { days }\end{array}$ & \multirow[t]{2}{*}{ Hepatocytes } & \multirow[t]{2}{*}{ Danio rerio } & \multicolumn{2}{|c|}{ 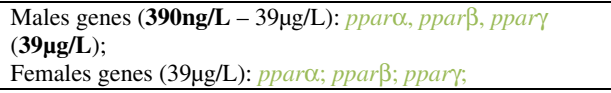 } & $\begin{array}{l}\text { (Maradonna et al., } \\
\text { 2013) }\end{array}$ \\
\hline PA & $\begin{array}{l}\mathbf{1 . 6 6} \mu \mathrm{g} / \mathrm{L}-1.66 \mathrm{mg} / \mathrm{L} ; \\
4 \text { days; }\end{array}$ & & & \multicolumn{2}{|c|}{$\begin{array}{l}\text { Males genes: } \text { pparo; } \text { ppar } \beta \\
\text { Females genes: } \text { ppar } \alpha ; \text { ppar } \beta\end{array}$} & \\
\hline $\mathrm{Cu}$ & $\begin{array}{l}\text { 635.5 } \mu \mathrm{g} / \mathrm{L}- \\
6.35 \mathrm{mg} / \mathrm{L} ; \\
24 \mathrm{~h} ; 48 \mathrm{~h} ; 96 \mathrm{~h} ;\end{array}$ & Hepatocytes & $\begin{array}{l}\text { Ctenopharyngodon } \\
\text { idellus }\end{array}$ & \multicolumn{2}{|c|}{ 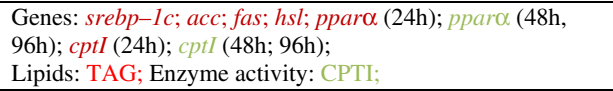 } & (Zhu et al., 2014) \\
\hline DiDP & $\begin{array}{l}\text { 44.7, } 446.7 \mu \mathrm{g} / \mathrm{L} \text { and } \\
4.5 \mathrm{mg} / \mathrm{L}\end{array}$ & Hepatocytes & Sparus aurata & \multicolumn{2}{|c|}{$\begin{array}{l}\text { Genes: pparo, ppar } \beta, \text { ppary, rxr } \alpha, c p t I a, c p t I b(446.7 \mu \mathrm{g} / \mathrm{L}) \text {, } \\
\text { fads2, scdla, scdlb, lpl, hl, fabp, apo-la and srebp }(44.7 \text {, } \\
446.7 \mu \mathrm{g} / \mathrm{L}) \text {; }\end{array}$} & (Cocci et al., 2015) \\
\hline
\end{tabular}

\section{Non-vertebrates}

In comparison with vertebrates, studies addressing the effects of putative obesogens in non-vertebrate taxa are scarce. Only a few studies have examined the chemical-induced disruption of lipid metabolism, mostly involving exposure to organotin compounds or complex mixtures.

\subsection{Tunicata}

\subsubsection{Organotins}

Ciona intestinalis ovaries exposed in vitro during $5 \mathrm{~h}$ to 0.33 and $32.6 \mu \mathrm{g} / \mathrm{L}$ TBT presented alterations in the lipid content. The increase in phospholipid levels and the decrease in TGA was proposed as a possible 
adaptive mechanism of resistance to the pollutant. An increase of the long chain fatty acids was also observed and related to an intensification of the membrane fluidity, which is in accordance with the capability of organotins to interact with membranes permeability (Puccia et al., 2005).

\subsection{Mollusca}

\subsubsection{Organotins}

Organotins also alter the lipid homeostasis in mollusks. TBT $(1.4 \mu \mathrm{g} / \mathrm{L})$ caused an increase in total lipids of female gastropod Marisa cornuarietis and a shift was observed in the proportion of the fatty acids (an increase in the monounsaturated fatty acids and a decrease in the polyunsaturated ones) after 100 days exposure (Janer et al., 2007). In contrast to TBT, a short exposure to TPT caused a decrease in female total lipids $(1.5 \mu \mathrm{g} / \mathrm{L})$ and in the total fatty acid levels (93.1 ng/ $\mathrm{L}-1.5 \mu \mathrm{g} / \mathrm{L}$ ) in Marisa cornuarietis after 7 days (Lyssimachou et al., 2009). In another gastropod species, Nucella lapillus, TBT exposure (100 ng/L-200 ng/L) caused alterations in the gene expression of key enzymes of fatty acid metabolism, indicated by the up-regulation of Acetyl-CoA synthetase (acs) and cptI (Pascoal et al., 2013). In vertebrates, both these genes are regulated by the heterodimer PPAR/RXR (Alaynick, 2008; Desvergne et al., 2006; Mello, 2010). The mechanism of action of these compounds in mollusks is still not well understood, although hypotheses involving modulation of NRs have been put forward. PPAR, RXR and ECR are the most likely candidates, although unlike RXR, that is present throughout metazoans, PPAR and ECR are not present in all non-vertebrate lineages (Jordão et al., 2016; Laguerre and Veenstra, 2010; Santos et al., 2012). Additional functional studies with mollusks PPAR and ECR have yet to be done which limits further interpretations.

\subsubsection{Other compounds}

The bivalve Dreissena polymorpha was exposed to clofibrate (200 ng/ $\mathrm{L}-2 \mathrm{mg} / \mathrm{L}$ ) for 7 days and exhibited a decrease in the total triacylglycerol levels and an increase in the fatty acid concentration in a dosedependent manner. The increase of fatty acids can be associated with the hydrolysis and consequent decrease of TAGs (Lazzara et al., 2012).

\subsubsection{Environmental mixtures}

In the environment, animals are not exposed solely to single compounds, but to complex mixtures, so it is essential to determine the effect of these complex mixtures in the metabolism (Lyche et al., 2013). A few studies have already linked oil pollution to lipid metabolic disorders. The mussel Mytilus edulis exposed to oil (0.05-2.5 ml/L) presented an increase in the gills total lipids (after 10 days) and TG levels (Fokina et al., 2014). An important point-source of xenobiotics to the aquatic ecosystems are municipal wastewaters. In the mussel Elliptio complanata exposure to $20 \% \mathrm{v} / \mathrm{v}$ of municipal wastewaters for 2 weeks induced an increase in gonads lipid content (Gagné et al., 2011). A relationship between environmental contamination and lipid metabolism disruption was also established in the field. The clam Scrobicularia plana was collected from three locations with different levels of contamination (Bay of St Brieuc (reference site), Goyen and Blavet estuaries), the Goyen and Blavet estuaries presented higher level of compounds with estrogenic activity and PAH. Total lipids and glycolipids were increased in the contaminated sites and the ratio TAG/Phospholipids was also altered, being higher in the Goyan estuary and lower in Blavet estuary (Perrat et al., 2013). The oyster Strombus gigas was collected from two sites with a high level of TBT (Road Harbour and Trellis Bay) and two reference sites (Guana Island and Anegada). A microarray analysis showed an alteration in the expression of lipid metabolismrelated genes for the Road Harbour and Trellis Bay sites when compared with the reference sites (Titley-O'Neal et al., 2013).

\subsection{Arthropoda}

\subsubsection{Organotins}

Daphnia magna (class:Branchiopoda) cultured from 4 to $8 \mathrm{~h}$ old at a high food rate was exposed to $0.1 \mu \mathrm{g} / \mathrm{L}$ and $1 \mu \mathrm{g} / \mathrm{L}$ of TBT during the adolescent instar and produced a progeny with less polyunsaturated fatty acids (PUFA) being the progeny less fit and smaller (Jordão et al., 2015). Additionally, levels of TBT (0.3-4.6 nM) that do not interfere with the feeding rate or the molt process lead to an increase in the lipid droplets of the D. magna individuals and an alteration in the expression pattern of several genes, including RXR and ECR. Interestingly, the increase in the lipid droplets was more pronounced in the animals with a higher food input. On the contrary, exposure to TPT $(2.6-5.2 \mathrm{nM})$ decreased lipid accumulation in the animals exposed during the adolescent instar (Jordão et al., 2016, 2015).

It has been demonstrated that Arthropoda, Mollusca and Annelida RXR can be activated by TBT and TPT (Nishikawa et al., 2004; Wang et al., 2011; Wang and LeBlanc, 2009; André et al., 2017). The knockdown of Drosophila ECR caused an increase in lipid accumulation, indicating that this NR may control the lipid accumulation in the fat body of this species (Kamoshida et al., 2012). In addition, in Daphnia magna the ECR agonist (20-hydroxyecdysone) caused an increase in lipid accumulation and the antagonist (fenarimol) caused a decrease (Jordão et al., 2016). Furthermore TBT, in addition to the induction of lipid accumulation in Daphnia magna, also caused a change in the expression of some ECR downstream genes (Jordão et al., 2015). This suggests that RXR/ECR is involved in the TBT-induced alterations of lipid metabolism in arthropods, possibly through RXR, since a number of studies could not find any transactivation of ECR in the presence of TBT (Verhaegen et al., 2011; Wang et al., 2011; Wang and LeBlanc, 2009). Whether TBT has a synergistic or antagonistic effect in the transactivation of the heterodimer, appears to be species-specific. Wang and colleagues observed that TBT increased the transactivation of the Daphnia magna heterodimer RXR/ECR in the presence of the ECR agonist (20-hydroxyecdysone) (Wang et al., 2011), but in the arthropod Crangon cangron TBT decreased the transactivation observed when RXR/ECR was exposed to an ECR agonist (Ponasterone A) (Verhaegen et al., 2011).

\subsubsection{Other compounds}

Three studies used the arthropod Daphnia magna to run a screening of the total body lipid content for a wide variety of compounds that were previously identified as obesogens in vertebrates: endogenous compounds, pesticides, NR agonists and pharmaceuticals (Jordão et al., 2016; Sancho et al., 2009; Villarroel et al., 2013). Methylfarnesoate, bisphenol A, pyriproxyfen and 20-hydroxyecdysone in concentration levels that do not affect feeding caused an increase in lipid levels, while fenarimol, fluoxetine, emamectin benzoate, nonylphenol, methoprene and di-2-ethylexyl phthalate, also in concentrations that do not affect feeding, caused a decrease in the lipid content (Jordão et al., 2016). Tebuconazol and propanil decreased lipid accumulation and the feeding rate in Daphnia magna (Sancho et al., 2009; Villarroel et al., 2013, 2003). In Metapenaeus monoceros (class: Malacostraca), exposure to Endosulfan (40 and $60 \mathrm{ng} / \mathrm{L}$ ), an insecticide and acaricide, during 23 days also led to a decrease in the total lipid content (Suryavanshi et al., 2009).

\subsubsection{Environmental mixtures}

Exposure of the arthropod Macrobrachium borellii to $0.6 \mathrm{mg} / \mathrm{L}$ of water-soluble fraction of crude oil for 7 days caused an increase in the activity of palmitoyl-CoA synthetase, TAG-lipase and $\beta$-oxidation, as well as in the TAG stores. The ratio Phospholipids/Triacylglycerol was also altered, being higher in eggs and lower in adults. The results suggest an increase in the energy production through an increment in the fatty acid oxidation (Lavarías et al., 2007, 2006) (See Table 3). 
Table 3

Summary of effects of environmental chemicals in non-vertebrate lipid homeostasis (green: up-regulated; red: down-regulated; n.d - not determined; bold-minimum effect concentration).

\begin{tabular}{|c|c|c|c|c|c|c|c|}
\hline \multirow[t]{2}{*}{ Compound } & \multirow{2}{*}{\multicolumn{2}{|c|}{ Exposure }} & \multirow[t]{2}{*}{ Species } & \multicolumn{3}{|c|}{ Endpoints } & \multirow[t]{2}{*}{ Ref. } \\
\hline & & & & Weight/Lipids alterations & $\begin{array}{l}\text { Alteration in gene } \\
\text { expression }\end{array}$ & $\begin{array}{c}\text { Biochemical } \\
\text { alterations }\end{array}$ & \\
\hline \multirow{2}{*}{ TBT } & \multicolumn{2}{|c|}{$\begin{array}{l}\mathbf{8 2 n g} / \mathrm{L}-1.4 \mu \mathrm{g} / \mathrm{L} \\
\text { (water); } \\
100 \text { days; }\end{array}$} & Marisa cornuarietis & $\begin{array}{l}\text { Lipids; } \\
\text { Fatty acids levels; }\end{array}$ & n.d & n.d & $\begin{array}{l}\text { (Janer et al., } \\
\text { 2007) }\end{array}$ \\
\hline & \multicolumn{2}{|c|}{$\begin{array}{l}\mathbf{1 0 0} \mathbf{n g} / \mathrm{L}-200 \mathrm{ng} / \mathrm{L} \\
\text { (water); } \\
3 \text { months; }\end{array}$} & Nucella lapillus & n.d & $a c s ; c p t I$ & n.d & $\begin{array}{l}\text { (Pascoal et al., } \\
\text { 2013) }\end{array}$ \\
\hline TPT & \multicolumn{2}{|c|}{$\begin{array}{l}\mathbf{9 3 . 1} \mathbf{~ n g} / \mathbf{L}-1.5 \mu \mathrm{g} / \mathrm{L} \\
\text { (water); } \\
7 \text { days; }\end{array}$} & Marisa cornuaietis & $\begin{array}{l}\text { Lipids; } \\
\text { Fatty acids levels; }\end{array}$ & n.d & n.d & $\begin{array}{l}\text { (Lyssimachou } \\
\text { et al., 2009) }\end{array}$ \\
\hline Clofibrate & \multicolumn{2}{|c|}{$\begin{array}{l}\text { 200ng/L }-2 \mathrm{mg} / \mathrm{L} \\
\text { (water); } \\
7 \text { days; }\end{array}$} & Dreissena polymorpha & $\begin{array}{l}\text { Triacylglycerol; } \\
\text { Fatty acids levels; }\end{array}$ & n.d & n.d & $\begin{array}{l}\text { (Lazzara et al., } \\
\text { 2012) }\end{array}$ \\
\hline Tebuconazole & \multicolumn{2}{|c|}{$\begin{array}{l}\mathbf{0 . 4 1}-1.14 \mathrm{mg} / \mathrm{L} \\
\text { (water); } \\
5 \text { days; }\end{array}$} & Daphnia magna & $\begin{array}{l}\text { Lipids; } \\
\text { Feeding rate; }\end{array}$ & n.d & n.d & $\begin{array}{l}\text { (Sancho et al., } \\
\text { 2009) }\end{array}$ \\
\hline Propanil & \multicolumn{2}{|l|}{$\begin{array}{l}\mathbf{0 . 0 7}-0.55 \mathrm{mg} / \mathrm{L} \\
\text { (water); } \\
5 \text { days; }\end{array}$} & Daphnia magna & Lipids; & n.d & n.d & $\begin{array}{l}\text { (Villarroel et } \\
\text { al., 2013) }\end{array}$ \\
\hline Endosulfan & \multicolumn{2}{|c|}{$\begin{array}{l}40 \text { and } 60 \mathrm{ng} / \mathrm{L} \text { (water); } \\
23 \text { days; }\end{array}$} & $\begin{array}{l}\text { Metapenaeus } \\
\text { monoceros }\end{array}$ & Lipids; & n.d & n.d & $\begin{array}{l}\text { (Suryavanshi } \\
\text { et al., 2009) }\end{array}$ \\
\hline Oil pollution & \multicolumn{2}{|c|}{$\begin{array}{l}\mathbf{0 . 0 5}-2.5 \mathrm{ml} / \mathrm{L} \\
10 \text { days; }\end{array}$} & Mytilus edulis & $\begin{array}{l}\text { Lipid (gills); } \\
\text { Triacylglycerol; } \\
\text { Phospholipids; } \\
\text { Cholesterol }(0.05 \mathrm{ml} / \mathrm{L}) \text {; } \\
\text { Cholesterol }(2.5 \mathrm{ml} / \mathrm{L}) \text {; }\end{array}$ & n.d & n.d & $\begin{array}{l}\text { (Fokina et al., } \\
\text { 2014) }\end{array}$ \\
\hline Crude oil & \multicolumn{2}{|l|}{$\begin{array}{l}\mathbf{0 . 6 m g} / \mathbf{L} \\
7 \text { days; }\end{array}$} & $\begin{array}{l}\text { Macrobrachium } \\
\text { borellii }\end{array}$ & $\begin{array}{l}\text { Lipid; } \\
\text { TAG; } \\
\text { Phospholipids/Triacylglycerol } \\
\text { (eggs); } \\
\text { Phospholipids/Triacylglycerol } \\
\text { (adults); }\end{array}$ & n.d & $\begin{array}{l}\text { PCS activity; } \\
\text { LPS activity; } \\
\beta \text {-oxidation; }\end{array}$ & $\begin{array}{l}\text { (Lavarías et } \\
\text { al., 2007, } \\
\text { 2006) }\end{array}$ \\
\hline TBT & \multicolumn{2}{|c|}{$\begin{array}{l}\mathbf{0 . 1} \text { and } 1 \mu \mathrm{g} / \mathrm{l} \text { (water); } \\
\text { Adolescent instar; }\end{array}$} & Daphnia magna & Lipid droplets; & $\begin{array}{l}\text { hr3; ecr } b \text {; neverland; } \\
\text { met; scr; hb2; rxr; }\end{array}$ & n.d & $\begin{array}{l}\text { (Jordão et al., } \\
\text { 2015) }\end{array}$ \\
\hline TBT & $\begin{array}{l}\mathbf{0 . 9 8 n g} / \mathrm{L}- \\
1.5 \mu \mathrm{g} / \mathrm{L} \\
\end{array}$ & & Daphnia magna & Lipid droplets; & n.d & n.d & $\begin{array}{l}\text { (Jordão et al., } \\
\text { 2016) }\end{array}$ \\
\hline Methyl farnesoate & $\mathbf{1 0}-250.3 \mu \mathrm{g} / \mathrm{L}$ & & & Lipid droplets; & n.d & n.d & \\
\hline BPA & $\begin{array}{l}299 \mu \mathrm{g} / \mathrm{L}- \\
10 \mathrm{mg} / \mathrm{L}\end{array}$ & & & Lipid droplets; & n.d & n.d & \\
\hline Pyriproxyfen & 51ng/L3ug/L; & 䓠 & & Lipid droplets; & n.d & n.d & \\
\hline $\begin{array}{c}20- \\
\text { hydroxyecdysone }\end{array}$ & $\begin{array}{l}9-480.64 \\
\mu \mathrm{g} / \mathrm{L}\end{array}$ & 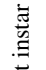 & & Lipid droplets; & n.d & n.d & \\
\hline Fenarimol & $\begin{array}{l}\text { 49.68 - } 298 \\
\mu \mathrm{g} / \mathrm{L} ;\end{array}$ & 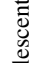 & & Lipid droplets; & n.d & n.d & \\
\hline Fluoxetine & $\begin{array}{l}\mathbf{1 5 . 5}-278.4 \\
\mu \mathrm{g} / \mathrm{L}\end{array}$ & $\frac{\pi}{0}$ & & Lipid droplets; & n.d & n.d & \\
\hline $\begin{array}{c}\text { Emamectin } \\
\text { benzoate }\end{array}$ & $\begin{array}{l}\text { 30.25 - } 201.65 \\
\text { ng/L; }\end{array}$ & $\stackrel{\Xi}{\Xi}$ & & Lipid droplets; & n.d & n.d & \\
\hline Nonylphenol & $\begin{array}{l}\mathbf{1 1 . 7}-103.35 \\
\mu \mathrm{g} / \mathrm{L} ;\end{array}$ & 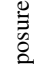 & & Lipid droplets; & n.d & n.d & \\
\hline Methoprene & $3-\mathbf{1 0 0} \mu \mathrm{g} / \mathrm{L}$ & 死 & & Lipid droplets; & n.d & n.d & \\
\hline Triphenyltin & $\begin{array}{l}\text { 221ng/L - } \\
1.9 \mu \mathrm{g} / \mathrm{L}\end{array}$ & & & Lipid droplets; & n.d & n.d & \\
\hline DEHP & $9.76-199 \mu \mathrm{g} / \mathrm{L}$ & & & Lipid droplets; & n.d & n.d & \\
\hline Compound & Exposure in vit & & System & Species & Endpoints & & Ref. \\
\hline TBT & $\mathbf{0 . 3 3}$ and $32.6 \mu \mathrm{g}$ & & Ovaries & Ciona intestinalis & $\begin{array}{l}\text { Phospholipid } 1 \\
\text { Triglycerides; }\end{array}$ & & $\begin{array}{l}\text { (Puccia et al., } \\
\text { 2005) }\end{array}$ \\
\hline
\end{tabular}

\section{Conclusions and research priorities}

Today it is well established that the adverse effects of EDCs on living organisms go beyond the interaction with the reproductive system and are not limited to mammals. Considering the crucial role of lipids in biological processes across metazoans, if we aim to protect biodiversity at an ecosystem scale, it is important to understand how chemicals affect metabolic pathways across different lineages, the interplay with the genetic repertoire and evolutionary histories and the significance of these alterations at the population level (Castro and Santos, 2014; Thornton, 2003; Adeogun et al., 2016a). Although our knowledge on the full spectra of taxa that can experience disruption of lipid homeostasis following chemical exposure is still limited, it is now recognized that a great variety of metazoans are impacted. The limited number of 


\section{Nuclear receptors \\ RXR PPAR LXR FXR ECR \\ Lipid \\ alterations}
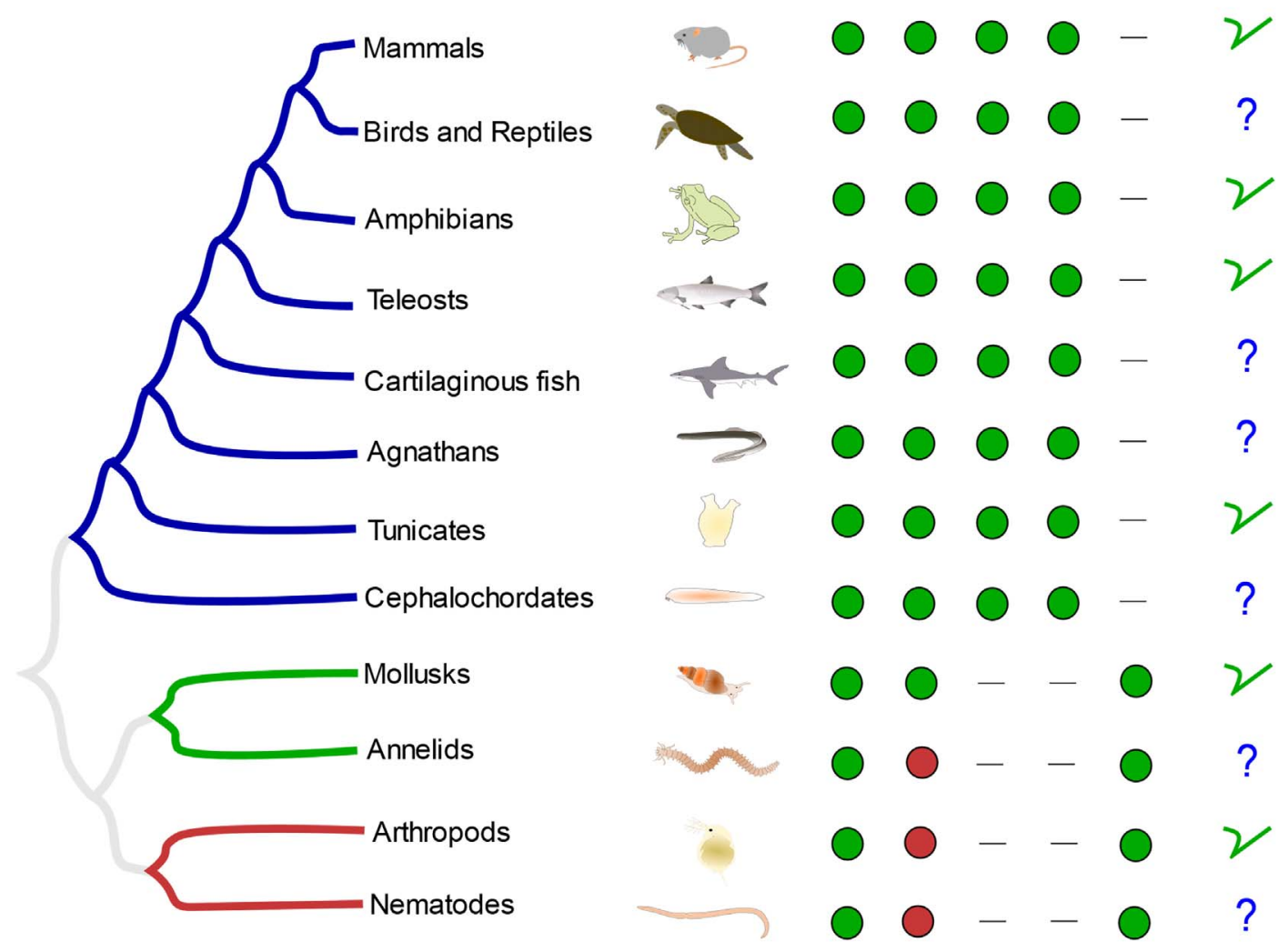

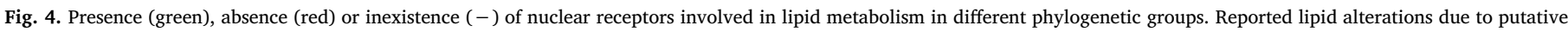

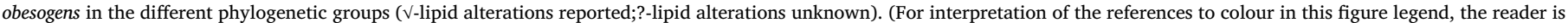
referred to the web version of this article.)

studies available indicate that the effects on lipid homeostasis manifest at different levels, i.e., alterations in the weight, fat content, total lipids content, fatty acids levels, enzyme activity and gene expression (Corcoran et al., 2015; Jordão et al., 2016; Lyssimachou et al., 2015; Riu et al., 2014).Alterations in the lipid homeostasis can cause major adverse effects in the organisms, since lipids have important roles in the overall metabolism and reproduction (Birsoy et al., 2013; Lyssimachou et al., 2015).

The assessment of the effects of obesogens at an ecosystem level is challenging. In fact, there are still major gaps in our knowledge of lipid homeostasis across lineages, despite the many shared features in the lipid metabolism of metazoans. The various NRs involved in lipid homeostasis are not transversally present in all animals and therefore, obesogens may interact differently across animal species. For example, RXR is present in most metazoans and is a common denominator of the NRs that can be implicated in lipid homeostasis, as it is the heterodimeric partner of PPAR, LXR, FXR and ECR, which are all involved, to a certain extent, in lipid regulation. While ECR has been characterized and genome predicted in some protostome taxa, LXR and FXR are deuterostomes novelties and PPAR is present in deuterostomes and in some protostomes lineages, i.e., mollusks (see Fig. 4) (Bertrand et al., 2004; Fonseca et al., 2017; Laguerre and Veenstra, 2010; Santos et al., 2012; Sladek, 2011; Vogeler et al., 2014).

The diversity of compounds able to bind and/or activate NRs is vast. In the NRs reported to regulate lipid metabolism, PPARs have been reported to bind to many different chemicals, probably due to the size of their binding pocket (Casals-Casas et al., 2008). LXR and FXR also interact with EDCs, such as phthalates and alkylphenols. For ECR, several insecticides (tebufenozide, halofenozide, methoxyfenozide, chromafenozide and fufenozide) were synthesized to exert their toxic action through this NR in arthropods (Dhadialla et al., 1998; Fahrbach et al., 2012). Whether ECR from taxa other than arthropods are also modulated by these insecticides remains to be investigated.

Although it is not possible to point to a single pathway for the adverse action of EDCs on lipid metabolism, several hypotheses are under scrutiny. Most known examples seem to implicate disruption of NRs signaling pathways. The modulation of NRs such as PPARs, LXR, FXR and ECR or their heterodimeric partner RXR can lead to a deregulation of the gene transcription and protein levels causing the disruption of the lipid homeostasis in a large range of analyzed taxa (Jordão et al., 2016; Ouadah-Boussouf and Babin, 2016; Riu et al., 2011; Santos et al., 2012). Yet, one of the major gaps of knowledge relates with the fact that in non-vertebrates, despite NRs have been predicted in most groups, as depicted in Fig. 4, NRs have been functionally characterized in a limited number of species. This hampers a more detailed analysis of the affected pathways and limits the use of NRs based-assays as a high throughput approach to screen the NR modulation by putative obesogens in a representative sample of Metazoans.

To fully understand the impact and the mode of action of environmental contaminants on lipid homeostasis across animal lineages, we must combine bioinformatics and both in vitro and an in vivo studies. These approaches will help to assess the potential of the numerous environmental contaminants to bind and activate/antagonize different NRs, the levels of gene transcription and protein activity and the physiological significance of these effects at the organism level. These approaches need to include a broad group of animal lineages, since some of the NRs involved in the lipid homeostasis are group-specific and the differences in the NR structure may determine distinct chemical 
binding and activation outcomes. Overall, a combination of approaches is fundamental to understand the involvement of NRs in the action of obesogens across the different animal phyla and to estimate the ecological consequences. This first requires functional characterization of NRs in representative taxa, then it will be important to disentangle the downstream signaling pathways which is today possible due to omics advances (e.g. various Next Generation Sequencing platforms, the advances in mass spectrometry in proteomics and metabolomics), thus identifying the genes and proteins regulated by each NR to expand our knowledge in the lipid homeostasis outside mammals. In addition, both laboratory and field studies are needed to evaluate the effects of suspected obesogens in different taxa given that for several lineages we still lack information (Fig. 4). This will establish the foundations to explore the obesogenic potential of suspected chemicals across different lineages. Many key questions still persist and should be the focus of future research; What is the taxonomic scope of lipid homeostasis perturbation by environmental chemicals? Are the observed effects reversible in the absence of the chemical insult? Are the observed effects transgenerational as has been suggested in mammalian models? If so, what is the role of epigenetic modifications? Are the affected pathways evolutionary conserved? To what extent obesogens impact ecologically relevant endpoints in exposed marine animal populations?

An evolutionary perspective is vital to understand the impact of obesogens at an ecosystem scale and address the major challenges raised above, and therefore contribute also for a better understanding of the etiology of obesity in human populations.

\section{Funding}

This work was supported by Norte2020 and FEDER (Coral-Sustainable Ocean Exploitation-Norte-01-0145-FEDER-000036). Ana Capitão was supported by the Fundação para a Ciência e a Tecnologia [SFRH/BD/ 90664/2012].

\section{Acknowledgements}

Animal images are a courtesy of the Integration and Application Network, University of Maryland Center for Environmental Science (ian.umces.edu/symbols/).

\section{References}

Liu, S. Ying, Jin, Q., Huang, X. Hui, Zhu, G. Nian, 2014. Disruption of zebrafish (Danio rerio) sexual development after full life-cycle exposure to environmental levels of triadimefon. Environ. Toxicol. Pharmacol. 37, 468-475. http://dx.doi.org/10.1016/ j.etap.2013.11.007.

Abidli, S., Lahbib, Y., Menif, N. El, 2009. Effects of TBT on the imposex development, reproduction and mortality in Hexaplex trunculus (Gastropoda: Muricidae). J. Mar. Biol. Assoc. UK 89, 139-146. http://dx.doi.org/10.1017/S0025315408002282.

Adeogun, A.O., Ibor, O.R., Onoja, A.B., Arukwe, A., 2016a. Fish condition factor, peroxisome proliferator activated receptors and biotransformation responses in Sarotherodon melanotheron from a contaminated freshwater dam (Awba Dam) in Ibadann Nigeria. Mar. Environ. Res. 121, 1-13. http://dx.doi.org/10.1016/j. marenvres.2016.02.002.

Adeogun, A.O., Ibor, O.R., Regoli, F., Arukwe, A., 2016b. Peroxisome proliferator-activated receptors and biotransformation responses in relation to condition factor and contaminant burden in tilapia species from Ogun River, Nigeria. Comp. Biochem. Physiol., Part C: Toxicol. Pharmacol. 183-184, 7-19. http://dx.doi.org/10.1016/j. cbpc.2015.12.006.

Alaynick, W.A., 2008. Nuclear receptors, mitochondria and lipid metabolism. Mitochondrion 8, 329-337. http://dx.doi.org/10.1016/j.mito.2008.02.001.

André, A., Ruivo, R., Capitão, A., Froufe, E., Páscoa, I., Costa Castro, L.F., Santos, M.M., 2017. Cloning and functional characterization of a retinoid $\mathrm{X}$ receptor orthologue in Platynereis dumerilii: An evolutionary and toxicological perspective. Chemosphere 182, 753-761. http://dx.doi.org/10.1016/j.chemosphere.2017.05.064.

Antizar-Ladislao, B., 2008. Environmental levels, toxicity and human exposure to tributyltin (TBT)-contaminated marine environment. A review. Environ. Int. 34, 292-308. http://dx.doi.org/10.1016/j.envint.2007.09.005.

Bašić, M., Butorac, A., Landeka Jurčević, I., Bačun-Družina, V., 2012. Obesity: genome and environment interactions. Arh. Hig. Rada Toksikol. 63, 395-405. http://dx.doi. org/10.2478/10004-1254-63-2012-2244.

Berg, J., Tymoczko, J., Stryer, L., 2002. Chapter 22: fatty acid metabolism. In: Biochemistry. W. H. Freeman, New York, pp. 897-942.
Berg, V., Lyche, J.L., Karlsson, C., Stavik, B., Nourizadeh-Lillabadi, R., Hårdnes, N., Skaare, J.U., Alestrøm, P., Lie, E., Ropstad, E., 2011. Accumulation and effects of natural mixtures of persistent organic pollutants (POP) in Zebrafish after two generations of exposure. J. Toxicol. Environ. Health A 74, 407-423. http://dx.doi.org/ 10.1080/15287394.2011.550455.

Bergman, Å., Heindel, J.J., Kasten, T., Kidd, K.A., Jobling, S., Neira, M., Zoeller, R.T., Becher, G., Bjerregaard, P., Bornman, R., Brandt, L., Kortenkamp, A., Muir, D., Drisse, M.B., Ochieng, R., Skakkebaek, N.E., Byléhn, A.S., Iguchi, T., 2013. Perspectives|editorial the impact of endocrine disruption: a consensus statement on the state of the science. Environ. Health Perspect. 121, 104-106. http://dx.doi.org/ 10.1289/ehp. 1205448 .

Berkenstam, A., Gustafsson, J.Å., 2005. Nuclear receptors and their relevance to diseases related to lipid metabolism. Curr. Opin. Pharmacol. 5, 171-176. http://dx.doi.org/ 10.1016/j.coph.2005.01.003.

Bertrand, S., Brunet, F.G., Escriva, H., Parmentier, G., Laudet, V., Robinson-Rechavi, M., 2004. Evolutionary genomics of nuclear receptors: from twenty-five ancestral genes to derived endocrine systems. Mol. Biol. Evol. 21, 1923-1937. http://dx.doi.org/10. 1093/molbev/msh200.

Biagianti-Risbourg, S., Bastide, J., 1995. Hepatic perturbations induced by a herbicide (atrazine) in juvenile grey mullet Liza ramada (Mugilidae, Teleostei): an ultrastructural study. Aquat. Toxicol. 31, 217-229. http://dx.doi.org/10.1016/0166-445X (94)00065-X.

Bility, M.T., Thompson, J.T., McKee, R.H., David, R.M., Butala, J.H., Vanden Heuvel, J.P., Peters, J.M., 2004. Activation of mouse and human peroxisome proliferator-activated receptors (PPARs) by phthalate monoesters. Toxicol. Sci. 82, 170-182. http://dx.doi. org/10.1093/toxsci/kfh253.

Birceanu, O., Servos, M.R., Vijayan, M.M., 2015. Bisphenol A accumulation in eggs disrupts the endocrine regulation of growth in rainbow trout larvae. Aquat. Toxicol. 161, 51-60. http://dx.doi.org/10.1016/j.aquatox.2015.01.028.

Birsoy, K., Festuccia, W.T., Laplante, M., 2013. A comparative perspective on lipid storage in animals. J. Cell Sci. 126, 1541-1552. http://dx.doi.org/10.1242/jcs.104992.

Bonefeld-Jørgensen, E.C., Long, M., Hofmeister, M.V., Vinggaard, A.M., 2007. Endocrinedisrupting potential of Bisphenol A, bisphenol A dimethacrylate, 4-n-nonylphenol, and 4-n-octylphenol in vitro: new data and a brief review. Environ. Health Perspect. 115, 69-76. http://dx.doi.org/10.1289/ehp.9368.

Brander, S.M., 2013. Endocrine Disruption in Aquatic Life. Elsevier B.V.http://dx.doi. org/10.1016/B978-0-444-59395-5.00005-4.

Brodin, T., Piovano, S., Fick, J., Klaminder, J., Heynen, M., Heynen, M., Jonsson, M., 2014. Ecological effects of pharmaceuticals in aquatic systems - impacts through behavioural alterations. Philos. Trans. R. Soc. B 369, 20130580. http://dx.doi.org/ 10.1098/rstb.2013.0580.

Brown, T., 2002. How genomes evolve. In: Genomes. Wiley-Liss, Oxford (Online).

Canesi, L., Fabbri, E., 2015. Environmental effects of BPA: focus on aquatic species. DoseResponse 13. http://dx.doi.org/10.1177/1559325815598304.

Carazo, A., Hyrsova, L., Dusek, J., Chodounska, H., Horvatova, A., Berka, K., Bazgier, V., Gan-schreier, H., Chamulitrat, W., Kudova, E., Pavek, P., 2017. Acetylated deoxycholic (DCA) and cholic (CA) acids are potent ligands of pregnane X (PXR) receptor. Toxicol. Lett. 265, 86-96. http://dx.doi.org/10.1016/j.toxlet.2016.11.013.

Casals-Casas, C., Feige, J.N., Desvergne, B., 2008. Interference of pollutants with PPARs: endocrine disruption meets metabolism. Int. J. Obes. 32 (Suppl. 6), S53-S61. http:// dx.doi.org/10.1038/ijo.2008.207.

Castro, L.F.C., Santos, M.M., 2014. To bind or not to bind: the taxonomic scope of nuclear receptor mediated endocrine disruption in invertebrate phyla. Environ. Sci. Technol. 48, 5361-5363. http://dx.doi.org/10.1021/es501697b.

Castro, L.F.C., Tocher, D.R., Monroig, O., 2016. Long-chain polyunsaturated fatty acid biosynthesis in chordates: insights into the evolution of Fads and Elovl gene repertoire. Prog. Lipid Res. 62, 25-40. http://dx.doi.org/10.1016/j.plipres.2016.01. 001.

Chamorro-García, R., Sahu, M., Abbey, R.J., Laude, J., Pham, N., Blumberg, B., 2013. Transgenerational inheritance of increased fat depot size, stem cell reprogramming, and hepatic steatosis elicited by prenatal exposure to the obesogen tributyltin in mice. Environ. Health Perspect. 121, 359-366. http://dx.doi.org/10.1289/ehp. 1205701.

Chen, Z., Chen, L., Chen, C., Huang, Q., Wu, L., Zhang, W., 2017. Organotin contamination in sediments and aquatic organisms from the Yangtze estuary and adjacent marine environments. Environ. Eng. Sci. 34, 227-235. http://dx.doi.org/10. 1089/ees.2016.0370.

Cocci, P., Mosconi, G., Arukwe, A., Mozzicafreddo, M., Angeletti, M., Aretusi, G., Palermo, F.A., 2015. Effects of diisodecyl phthalate on PPAR:RXR-dependent gene expression pathways in sea bream hepatocytes. Chem. Res. Toxicol. 28, 935-947. http://dx.doi.org/10.1021/tx500529x.

Coimbra, A.M., Peixoto, M.J., Coelho, I., Lacerda, R., Carvalho, A.P., Gesto, M., Lyssimachou, A., Lima, D., Soares, J., André, A., Capitão, A., Castro, L.F.C., Santos, M.M., 2015. Chronic effects of clofibric acid in zebrafish (Danio rerio): a multigenerational study. Aquat. Toxicol. 160, 76-86. http://dx.doi.org/10.1016/j. aquatox.2015.01.013.

Corcoran, J., Winter, M.J., Tyler, C.R., 2010. Pharmaceuticals in the aquatic environment: a critical review of the evidence for health effects in fish. Crit. Rev. Toxicol. 40 287-304. http://dx.doi.org/10.3109/10408440903373590.

Corcoran, J., Winter, M.J., Lange, A., Cumming, R., Owen, S.F., Tyler, C.R., 2015. Effects of the lipid regulating drug clofibric acid on PPAR $\alpha$-regulated gene transcript levels in common carp (Cyprinus carpio) at pharmacological and environmental exposure levels. Aquat. Toxicol. 161, 127-137. http://dx.doi.org/10.1016/j.aquatox.2015.01. 033.

Crow, K.D., Wagner, G.P., 2006. What is the role of genome duplication in the evolution of complexity and diversity? Mol. Biol. Evol. 23, 887-892. http://dx.doi.org/10 
1093/molbev/msj083.

David, A., Fenet, H., Gomez, E., 2009. Alkylphenols in marine environments: distribution monitoring strategies and detection considerations. Mar. Pollut. Bull. 58, 953-960. http://dx.doi.org/10.1016/j.marpolbul.2009.04.021.

De Cock, M., Van de Bor, M., 2014. Obesogenic effects of endocrine disruptors, what do we know from animal and human studies? Environ. Int. 70, 15-24. http://dx.doi.org/ 10.1016/j.envint.2014.04.022.

Den Broeder, M.J., Kopylova, V.A., Kamminga, L.M., Legler, J., 2015. Zebrafish as a model to study the role of peroxisome proliferating-activated receptors in adipogenesis and obesity. PPAR Res. 2015. http://dx.doi.org/10.1155/2015/358029.

Desvergne, B., Michalik, L., Wahli, W., 2006. Transcriptional regulation of metabolism. Physiol. Rev. 86, 465-514. http://dx.doi.org/10.1152/physrev.00025.2005.

Dhadialla, T.S., Carlson, G.R., Le, D.P., 1998. New insecticides with ecdysteroidal and juvenile hormone activity. Annu. Rev. Entomol. 43, 545-569. http://dx.doi.org/10. 1146/annurev.ento.43.1.545.

Diamanti-Kandarakis, E., Bourguignon, J.-P., Giudice, L.C., Hauser, R., Prins, G.S., Soto, A.M., Zoeller, R.T., Gore, A.C., 2009. Endocrine-disrupting chemicals: an endocrine society scientific statement. Endocr. Rev. 30, 293-342. http://dx.doi.org/10.1210/ er.2009-0002

Dimastrogiovanni, G., Córdoba, M., Navarro, I., Jáuregui, O., Porte, C., 2015. Alteration of cellular lipids and lipid metabolism markers in RTL-W1 cells exposed to model endocrine disrupters. Aquat. Toxicol. 165, 277-285. http://dx.doi.org/10.1016/j aquatox.2015.06.005.

Eberlé, D., Hegarty, B., Bossard, P., Ferré, P., Foufelle, F., 2004. SREBP transcription factors: master regulators of lipid homeostasis. Biochimie 86, 839-848. http://dx.doi. org/10.1016/j.biochi.2004.09.018.

Emblidge, J.P., DeLorenzo, M.E., 2006. Preliminary risk assessment of the lipid-regulating pharmaceutical clofibric acid, for three estuarine species. Environ. Res. 100, 216-226. http://dx.doi.org/10.1016/j.envres.2005.03.014.

Evans, R.M., Mangelsdorf, D.J., 2014. Nuclear receptors, RXR, and the big bang. Cell 157, 255-266. http://dx.doi.org/10.1016/j.cell.2014.03.012.

Fabbrini, E., Sullivan, S., Klein, S., 2010. Obesity and nonalcoholic fatty liver disease: biochemical, metabolic and clinical Implications. Hepatology 51, 679-689. http:// dx.doi.org/10.1002/hep.23280.Obesity.

Fahrbach, S.E., Smagghe, G., Velarde, R.A., 2012. Insect nuclear receptors. Annu. Rev. Entomol. 57, 83-106. http://dx.doi.org/10.1146/annurev-ento-120710-100607.

Feige, J.N., Gelman, L., Rossi, D., Zoete, V., Métivier, R., Tudor, C., Anghel, S.I., Grosdidier, A., Lathion, C., Engelborghs, Y., Michielin, O., Wahli, W., Desvergne, B., 2007. The endocrine disruptor monoethyl-hexyl-phthalate is a selective peroxisome proliferator-activated receptor $\gamma$ modulator that promotes adipogenesis. J. Biol. Chem. 282, 19152-19166. http://dx.doi.org/10.1074/jbc.M702724200.

Ferreira, F., Santos, M.M., Castro, L.F.C., Reis-Henriques, M.A., Lima, D., Vieira, M.N. Monteiro, N.M., 2009. Vitellogenin gene expression in the intertidal blenny Lipophrys pholis: a new sentinel species for estrogenic chemical pollution monitoring in the European Atlantic coast? Comp. Biochem. Physiol., Part C: Toxicol. Pharmacol. 149, 58-64. http://dx.doi.org/10.1016/j.cbpc.2008.07.002.

Flint, S., Markle, T., Thompson, S., Wallace, E., 2012. Bisphenol A exposure, effects, and policy: a wildlife perspective. J. Environ. Manag. 104, 19-34. http://dx.doi.org/10. 1016/j.jenvman.2012.03.021.

Flynn, E.J., Trent, C.M., Rawls, J.F., 2009. Ontogeny and nutritional control of adipogenesis in zebrafish (Danio rerio). J. Lipid Res. 50, 1641-1652. http://dx.doi.org/10. 1194/jlr.M800590-JLR200.

Fokina, N.N., Bakhmet, I.N., Shklyarevich, G.A., Nemova, N.N., 2014. Effect of seawater desalination and oil pollution on the lipid composition of blue mussels Mytilus edulis L. from the White Sea. Ecotoxicol. Environ. Saf. 110, 103-109. http://dx.doi.org/10. 1016/j.ecoenv.2014.08.010.

Fonseca, E., Ruivo, R., Lopes-Marques, M., Zhang, H., Santos, M.M., Venkatesh, B., Castro, L.F.C., 2017. LXR $\alpha$ and LXR $\beta$ nuclear receptors evolved in the common ancestor of gnathostomes. Genome Biol. Evol, evw305. http://dx.doi.org/10.1093/gbe/evw305.

Fromme, H., Küchler, T., Otto, T., Pilz, K., Müller, J., Wenzel, A., 2002. Occurrence of phthalates and bisphenol A and F in the environment. Water Res. 36, 1429-1438. http://dx.doi.org/10.1016/S0043-1354(01)00367-0.

Fukazawa, H., Watanabe, M., Shiraishi, F., Shiraishi, H., Shiozawa, T., Matsushita, H., Terao, Y., 2002. Formation of chlorinated derivatives of bisphenol A in waste paper recycling plants and their estrogenic activities. J. Health Sci. 48, 242-249. http://dx. doi.org/10.1248/jhs.48.242

Gagné, F., André, C., Cejka, P., Hausler, R., Fournier, M., 2011. Evidence of neuroendocrine disruption in freshwater mussels exposed to municipal wastewaters. Sci. Total Environ. 409, 3711-3718. http://dx.doi.org/10.1016/j.scitotenv.2011.04.037.

García-Mayor, R.V., Larrañaga Vidal, A., Docet Caamaño, M.F., Lafuente Giménez, A. 2012. Endocrine disruptors and obesity: obesogens. Endocrinol. Nutr. 59, 261-267. (English Ed.). http://dx.doi.org/10.1016/j.endoen.2012.05.001.

Gipperth, L., 2009. The legal design of the international and European Union ban on tributyltin antifouling paint: direct and indirect effects. J. Environ. Manag. 90, 86-95. http://dx.doi.org/10.1016/j.jenvman.2008.08.013.

Grün, F., Blumberg, B., 2006. Environmental obesogens: organotins and endocrine disruption via nuclear receptor signaling. Endocrinology 147, 50-55. http://dx.doi.org/ 10.1210/en.2005-1129.

Grün, F., Blumberg, B., 2007. Perturbed nuclear receptor signaling by environmental obesogens as emerging factors in the obesity crisis. Rev. Endocr. Metab. Disord. 8, 161-171. http://dx.doi.org/10.1007/s11154-007-9049-x.

Grün, F., Blumberg, B., 2009a. Minireview: the case for obesogens. Mol. Endocrinol. 23, 1127-1134. http://dx.doi.org/10.1210/me.2008-0485.

Grün, F., Blumberg, B., 2009b. Endocrine disrupters as obesogens. Mol. Cell. Endocrinol. 304, 19-29. http://dx.doi.org/10.1016/j.mce.2009.02.018.

Grün, F., Watanabe, H., Zamanian, Z., Maeda, L., Arima, K., Cubacha, R., Gardiner, D.M.,
Kanno, J., Iguchi, T., Blumberg, B., 2006. Endocrine-disrupting organotin compounds are potent inducers of adipogenesis in vertebrates. Mol. Endocrinol. 20, 2141-2155. http://dx.doi.org/10.1210/me.2005-0367.

Guan, Y., Gao, J., Zhang, Y., Chen, S., Yuan, C., Wang, Z., 2016. Effects of bisphenol A on lipid metabolism in rare minnow Gobiocypris rarus. Comp. Biochem. Physiol., Part C: Toxicol. Pharmacol. 179, 144-149. http://dx.doi.org/10.1016/j.cbpc.2015.10.006.

Hao, C., Cheng, X., Guo, J., Xia, H., Ma, X., 2013. Perinatal exposure to diethyl-hexylphthalate induces obesity in mice. Front. Biosci. 5, 725-733.

Harada, S., Hiromori, Y., Nakamura, S., Kawahara, K., Fukakusa, S., Maruno, T., Noda, M., Uchiyama, S., Fukui, K., Nishikawa, J., Nagase, H., Kobayashi, Y., Yoshida, T., Ohkubo, T., Nakanishi, T., 2015. Structural basis for PPAR $\gamma$ transactivation by endocrine-disrupting organotin compounds. Sci Rep 5, 8520. http://dx.doi.org/10. 1038/srep08520.

Higley, E., Tompsett, A.R., Giesy, J.P., Hecker, M., Wiseman, S., 2013. Effects of triphenyltin on growth and development of the wood frog (Lithobates sylvaticus). Aquat. Toxicol. 144-145, 155-161. http://dx.doi.org/10.1016/j.aquatox.2013.09.029.

Hiromori, Y., Nishikawa, J., Yoshida, I., Nagase, H., Nakanishi, T., 2009. Structure-dependent activation of peroxisome proliferator-activated receptor (PPAR) gamma by organotin compounds. Chem. Biol. Interact. 180, 238-244. http://dx.doi.org/10. 1016/j.cbi.2009.03.006.

Holtcamp, W., 2012. Obesogens: an environmental link to obesity. Environ. Health Perspect. 120. http://dx.doi.org/10.1289/ehp.120-a62.

Hurst, C.H., Waxman, D.J., 2003. Activation of PPAR $\alpha$ and PPAR $\gamma$ by environmental phthalate monoesters. Toxicol. Sci. 74, 297-308. http://dx.doi.org/10.1093/toxsci/ kfg145.

Imrie, D., Sadler, K.C., 2010. White adipose tissue development in zebrafish is regulated by both developmental time and fish size. Dev. Dyn. 239, 3013-3023. http://dx.doi. org/10.1002/dvdy.22443.

Janer, G., Navarro, J.C., Porte, C., 2007. Exposure to TBT increases accumulation of lipids and alters fatty acid homeostasis in the ramshorn snail Marisa cornuarietis. Comp. Biochem. Physiol., Part C: Toxicol. Pharmacol. 146, 368-374. http://dx.doi.org/10. 1016/j.cbpc.2007.04.009.

Janesick, A., Blumberg, B., 2011. Minireview: PPAR $\gamma$ as the target of obesogens. J. Steroid Biochem. Mol. Biol. 127, 4-8. http://dx.doi.org/10.1016/j.jsbmb.2011.01.005.

Jenner, R., 2007. Metazoan phylogeny. In: Evolution of Nervous Systems. Elsevier Inc., Bath, pp. 17-40. http://dx.doi.org/10.1016/B0-12-370878-8/00106-3.

Jordão, R., Casas, J., Fabrias, G., Campos, B., Piña, B., Lemos, M.F.L., Soares, A.M.V.M., Tauler, R., Barata, C., 2015. Obesogens beyond vertebrates: lipid perturbation by tributyltin in the crustacean Daphnia magna. Environ. Health Perspect. 123, 813-819. http://dx.doi.org/10.1289/ehp.1409163.

Jordão, R., Garreta, E., Campos, B., Lemos, M.F.L., Soares, A.M.V.M., Tauler, R., Barata, C., 2016. Compounds altering fat storage in Daphnia magna. Sci. Total Environ. 545-546, 127-136. http://dx.doi.org/10.1016/j.scitotenv.2015.12.097.

Kabir, E.R., Rahman, M.S., Rahman, I., 2015. A review on endocrine disruptors and their possible impacts on human health. Environ. Toxicol. Pharmacol. 40, 241-258. http:// dx.doi.org/10.1016/j.etap.2015.06.009.

Kamoshida, Y., Fujiyama-Nakamura, S., Kimura, S., Suzuki, E., Lim, J., Shiozaki-Sato, Y., Kato, S., Takeyama, K. Ichi, 2012. Ecdysone receptor (EcR) suppresses lipid accumulation in the drosophila fat body via transcription control. Biochem. Biophys. Res. Commun. 421, 203-207. http://dx.doi.org/10.1016/j.bbrc.2012.03.135.

Kanayama, T., Kobayashi, N., Mamiya, S., Nakanishi, T., Nishikawa, J., 2005. Organotin compounds promote adipocyte differentiation as agonists of the peroxisome proliferator-activated receptor $\gamma /$ retinoid X receptor pathway. Mol. Pharmacol. 67, 766-774. http://dx.doi.org/10.1124/mol.104.008409.family.

Klimentidis, Y.C., Beasley, T.M., Lin, H., Murati, G., Glass, G.E., Guyton, M., Newton, W., Jorgensen, M., Heymsfield, S.B., Kemnitz, J., Fairbanks, L., Allison, D.B., 2011. Canaries in the coal mine: a cross-species analysis of the plurality of obesity epidemics 1626-1632. http://dx.doi.org/10.1098/rspb.2010.1890.

Kramarova, T.V., Dahlman Wright, K., Pongratz, I., 2009. The role of the estrogen receptors in obesity. Drug Discov. Today Dis. Mech. 6, e49-e54. http://dx.doi.org/10. 1016/j.ddmec.2009.11.001.

Laguerre, M., Veenstra, J.A., 2010. Ecdysone receptor homologs from mollusks, leeches and a polychaete worm. FEBS Lett. 584, 4458-4462. http://dx.doi.org/10.1016/j. febslet.2010.10.004.

Langerveld, A.J., Celestine, R., Zaya, R., Mihalko, D., Ide, C.F., 2009. Chronic exposure to high levels of atrazine alters expression of genes that regulate immune and growthrelated functions in developing Xenopus laevis tadpoles. Environ. Res. 109, 379-389. http://dx.doi.org/10.1016/j.envres.2009.01.006.

Lavarías, S., Pollero, R.J., Heras, H., 2006. Activation of lipid catabolism by the watersoluble fraction of petroleum in the crustacean Macrobrachium borellii. Aquat. Toxicol. 77, 190-196. http://dx.doi.org/10.1016/j.aquatox.2005.12.002.

Lavarías, S., García, F., Pollero, R.J., Heras, H., 2007. Effect of the water-soluble fraction of petroleum on microsomal lipid metabolism of Macrobrachium borellii (Arthropoda: Crustacea). Aquat. Toxicol. 82, 265-271. http://dx.doi.org/10.1016/j.aquatox.2007. 02.017.

Lavarías, S., Pasquevich, M.Y., Dreon, M.S., Heras, H., 2009. Partial characterization of a malonyl-CoA-sensitive carnitine O-palmitoyltransferase I from Macrobrachium borelli (Crustacea: Palaemonidae). Comp. Biochem. Physiol. B Biochem. Mol. Biol. 152, 364-369. http://dx.doi.org/10.1016/j.cbpb.2009.01.004.

Lazzara, R., Fernandes, D., Faria, M., López, J.F., Tauler, R., Porte, C., 2012. Changes in lipid content and fatty acid composition along the reproductive cycle of the fresh water mussel Dreissena polymorpha: its modulation by clofibrate exposure. Sci. Total Environ. 432, 195-201. http://dx.doi.org/10.1016/j.scitotenv.2012.05.094.

Leaver, M.J., Boukouvala, E., Antonopoulou, E., Diez, A., Favre-Krey, L., Tariq Ezaz, M., Bautista, J.M., Tocher, D.R., Krey, G., 2005. Three peroxisome proliferator-activated receptor isotypes from each of two species of marine fish. Endocrinology 146, 
3150-3162. http:/dx doi.org/10.1210/en. 2004-1638.

Legler, J., Fletcher, T., Govarts, E., Porta, M., Blumberg, B., Heindel, J.J., Trasande, L. 2015. Obesity, diabetes, and associated costs of exposure to endocrine-disrupting chemicals in the European Union. J. Clin. Endocrinol. Metab. 100, 1278-1288. http://dx.doi.org/10.1210/jc.2014-4326.

Lempradl, A., Pospisilik, J.A., Penninger, J.M., 2015. Exploring the emerging complexity in transcriptional regulation of energy homeostasis. Nat. Rev. Genet. 16, 665-681. http://dx.doi.org/10.1038/nrg3941.

Li, Z.H., Li, P., Shi, Z.C., 2014. Molecular responses in digestive tract of juvenile common carp after chronic exposure to sublethal tributyltin. Ecotoxicol. Environ. Saf. 109, 10-14. http://dx.doi.org/10.1016/j.ecoenv.2014.07.031.

Lim, S., Ahn, S.Y., Song, I.C., Chung, M.H., Jang, H.C., Park, K.S., Pak, Y.K., Lee, H.K., 2009. Chronic exposure to the herbicide, atrazine, causes mitochondrial dysfunction and insulin resistance. PLoS One 4. http://dx.doi.org/10.1371/journal.pone. 0005186.

Lima, D., Reis-Henriques, M.A., Silva, R., Santos, A.I., Castro, Filipe C.L., Santos, M.M., 2011. Tributyltin-induced imposex in marine gastropods involves tissue-specific modulation of the retinoid X receptor. Aquat. Toxicol. 101, 221-227. http://dx.doi. $\operatorname{org} / 10.1016 /$ j.aquatox.2010.09.022.

Lundin, L.G., 1999. Gene duplications in early metazoan evolution. Semin. Cell Dev. Biol. 10, 523-530. http://dx.doi.org/10.1006/scdb.1999.0333.

Lyche, J.L., Nourizadeh-Lillabadi, R., Karlsson, C., Stavik, B., Berg, V., Skåre, J.U., Alestrøm, P., Ropstad, E., 2011. Natural mixtures of POPs affected body weight gain and induced transcription of genes involved in weight regulation and insulin signaling. Aquat. Toxicol. 102, 197-204. http://dx.doi.org/10.1016/j.aquatox.2011.01. 017

Lyche, J.L., Grześ, I.M., Karlsson, C., Nourizadeh-Lillabadi, R., Berg, V., Kristoffersen, A.B., Skåre, J.U., Alestrøm, P., Ropstad, E., 2013. Parental exposure to natural mixtures of POPs reduced embryo production and altered gene transcription in zebrafish embryos. Aquat. Toxicol. 126, 424-434. http://dx.doi.org/10.1016/j.aquatox.2012. 08.019.

Lyssimachou, A., Navarro, J.C., Bachmann, J., Porte, C., 2009. Triphenyltin alters lipid homeostasis in females of the ramshorn snail Marisa cornuarietis. Environ. Pollut. 157, 1714-1720. http://dx.doi.org/10.1016/j.envpol.2008.12.013.

Lyssimachou, A., Santos, J.G., André, A., Soares, J., Lima, D., Guimarães, L., Almeida, C.M.R., Teixeira, C., Castro, L.F.C., Santos, M.M., 2015. The mammalian "obesogen" tributyltin targets hepatic triglyceride accumulation and the transcriptional regulation of lipid metabolism in the liver and brain of zebrafish. PLoS One 10, 1-22. http://dx.doi.org/10.1371/journal.pone.0143911.

le Maire, A., Grimaldi, M., Roecklin, D., Dagnino, S., Vivat-Hannah, V., Balaguer, P., Bourguet, W., 2009. Activation of RXR-PPAR heterodimers by organotin environmental endocrine disruptors. EMBO Rep. 10, 367-373. http://dx.doi.org/10.1038/ embor.2009.8.

Maisano, M., Cappello, T., Oliva, S., Natalotto, A., Giannetto, A., Parrino, V., Battaglia, P., Romeo, T., Salvo, A., Spanò, N., Mauceri, A., 2015. PCB and OCP accumulation and evidence of hepatic alteration in the Atlantic bluefin tuna, T. thynnus, from the Mediterranean Sea. Mar. Environ. Res. 121, 40-48. http://dx.doi.org/10.1016/j. marenvres.2016.03.003.

Maradonna, F., Evangelisti, M., Gioacchini, G., Migliarini, B., Olivotto, I., Carnevali, O., 2013. Assay of vtg, ERs and PPARs as endpoint for the rapid in vitro screening of the harmful effect of Di-(2-ethylhexyl)-phthalate (DEHP) and phthalic acid (PA) in zebrafish primary hepatocyte cultures. Toxicol. in Vitro 27, 84-91. http://dx.doi.org/10. 1016/j.tiv.2012.09.018

Maradonna, F., Nozzi, V., Santangeli, S., Traversi, I., Gallo, P., Fattore, E., Mita, D.G., Mandich, A., Carnevali, O., 2015. Xenobiotic-contaminated diets affect hepatic lipid metabolism: Implications for liver steatosis in Sparus aurata juveniles. Aquat. Toxicol. 167, 257-264. http://dx.doi.org/10.1016/j.aquatox.2015.08.006.

Masuno, H., Iwanami, J., Kidani, T., Sakayama, K., Honda, K., 2005. Bisphenol A accelerates terminal differentiation of 3T3-L1 cells into adipocytes through the phosphatidylinositol 3-kinase pathway. Toxicol. Sci. 84, 319-327. http://dx.doi.org/10. 1093/toxsci/kfi088.

Mathieu-Denoncourt, J., de Solla, S.R., Langlois, V.S., 2015. Chronic exposures to monomethyl phthalate in western clawed frogs. Gen. Comp. Endocrinol. 219, 53-63. http://dx.doi.org/10.1016/j.ygcen.2015.01.019.

Maynard, R., 2002. Late lessons from early warnings: the precautionary principle 1896-2000. Occup. Environ. Med. http://dx.doi.org/10.1136/oem.59.11.789-a.

McCarthy, I.D., Fuiman, L.A., 2008. Growth and protein metabolism in red drum (Sciaenops ocellatus) larvae exposed to environmental levels of atrazine and malathion. Aquat. Toxicol. 88, 220-229. http://dx.doi.org/10.1016/j.aquatox.2008.05. 001.

Meador, J.P., Sommers, F.C., Cooper, K.A., Yanagida, G., 2011. Tributyltin and the obesogen metabolic syndrome in a salmonid. Environ. Res. 111, 50-56. http://dx. doi.org/10.1016/j.envres.2010.11.012.

Meggs, W.J., Brewer, K.L., 2007. Weight Gain Associated with Chronic Exposure to Chlorpyrifos in Rats. pp. 3.

Mello, T., 2010. Nuclear receptors in the control of lipid metabolism. Curr. Cardiovasc Risk Rep. 4, 142-149. http://dx.doi.org/10.1007/s12170-010-0080-1.

Melvin, S.D., 2016. Oxidative stress, energy storage, and swimming performance of Limnodynastes peronii tadpoles exposed to a sub-lethal pharmaceutical mixture throughout development. Chemosphere 150, 790-797. http://dx.doi.org/10.1016/j. chemosphere.2015.09.034.

Milić, S., Lulić, D., Štimac, D., 2014. Non-alcoholic fatty liver disease and obesity: biochemical, metabolic and clinical presentations. World J. Gastroenterol. 20, 9330-9337. http://dx.doi.org/10.3748/wjg.v20.i28.9330.

Mozzicafreddo, M., Cuccioloni, M., Bonfili, L., Cecarini, V., Palermo, F.A., Cocci, P., Mosconi, G., Capone, A., Ricci, I., Eleuteri, A.M., Angeletti, M., 2015. Environmental pollutants directly affect the liver $\mathrm{X}$ receptor alpha activity: kinetic and thermodynamic characterization of binding. J. Steroid Biochem. Mol. Biol. 152, 1-7. http:// dx.doi.org/10.1016/j.jsbmb.2015.04.011.

Nelson, D., Cox, M., Lehninger, A., 2005. Chapter 10: Lipids. In: Lehninger Principles of Biochemistry. W. H. Freeman, pp. 343-368. http://dx.doi.org/10.1002/bmb.2005 494033010419.

Nerlov, C., 2007. The C/EBP family of transcription factors: a paradigm for interaction between gene expression and proliferation control. Trends Cell Biol. 17, 318-324. http://dx.doi.org/10.1016/j.tcb.2007.07.004.

Nishikawa, J.I., Mamiya, S., Kanayama, T., Nishikawa, T., Shiraishi, F., Horiguchi, T., 2004. Involvement of the retinoid $X$ receptor in the development of imposex caused by organotins in gastropods. Environ. Sci. Technol. 38, 6271-6276. http://dx.doi. org/10.1021/es049593u.

Nourizadeh-Lillabadi, R., Lyche, J.L., Almaas, C., Stavik, B., Moe, S.J., Aleksandersen, M., Berg, V., Jakobsen, K.S., Stenseth, N.C., Skåre, J.U., Alestrøm, P., Ropstad, E., 2009. Transcriptional regulation in liver and testis associated with developmental and reproductive effects in male zebrafish exposed to natural mixtures of persistent organic pollutants (POP). J. Toxic. Environ. Health A 72, 112-130. http://dx.doi.org/10. 1080/15287390802537255.

Nunes, B., Carvalho, F., Guilhermino, L., 2004. Acute and chronic effects of clofibrate and clofibric acid on the enzymes acetylcholinesterase, lactate dehydrogenase and catalase of the mosquitofish, Gambusia holbrooki. Chemosphere 57, 1581-1589. http:// dx.doi.org/10.1016/j.chemosphere.2004.09.018.

Ollikainen, N., Chandsawangbhuwana, C., Baker, M.E., 2006. Evolution of the thyroid hormone, retinoic acid, ecdysone and liver X receptors. Integr. Comp. Biol. 46, 815-826. http://dx.doi.org/10.1093/icb/icl035.

Ouadah-Boussouf, N., Babin, P.J., 2016. Pharmacological evaluation of the mechanisms involved in increased adiposity in zebrafish triggered by the environmental contaminant tributyltin. Toxicol. Appl. Pharmacol. 294, 32-42. http://dx.doi.org/10. 1016/j.taap.2016.01.014.

Pait, A.S., Nelson, J.O., 2002. Endocrine disruption in fish, an assessment of recent research and results. NOAA Tech. Memo. NOS NCCOS CCMA 149, 1-55.

Pascoal, S., Carvalho, G., Vasieva, O., Hughes, R., Cossins, A., Fang, Y., Ashelford, K., Olohan, L., Barroso, C., Mendo, S., Creer, S., 2013. Transcriptomics and in vivo tests reveal novel mechanisms underlying endocrine disruption in an ecological sentinel, Nucella lapillus. Mol. Ecol. 22, 1589-1608. http://dx.doi.org/10.1111/mec.12137.

Pennington, P.L., Daugomah, J.W., Colbert, A.C., Fulton, M.H., Key, P.B., Thompson, B.C., Erich, D., Scott, G.I., 2001. Mid-Texas estuaries and risk assessment implications for marine phytoplankton. J. Environ. Sci. Health B 36, 1-14. http://dx.doi.org/10. 1081/PFC-100000912.

Pereira-Fernandes, A., Vanparys, C., Hectors, T.L.M., Vergauwen, L., Knapen, D., Jorens, P.G., Blust, R., 2013. Unraveling the mode of action of an obesogen: mechanistic analysis of the model obesogen tributyltin in the 3T3-L1 cell line. Mol. Cell. Endocrinol. 370, 52-64. http://dx.doi.org/10.1016/j.mce.2013.02.011.

Perrat, E., Couzinet-Mossion, A., Fossi Tankoua, O., Amiard-Triquet, C., Wielgosz-Collin, G., 2013. Variation of content of lipid classes, sterols and fatty acids in gonads and digestive glands of Scrobicularia plana in relation to environment pollution levels. Ecotoxicol. Environ. Saf. 90, 112-120. http://dx.doi.org/10.1016/j.ecoenv.2012.12. 019.

Prindiville, J.S., Mennigen, J.A., Zamora, J.M., Moon, T.W., Weber, J.M., 2011. The fibrate drug gemfibrozil disrupts lipoprotein metabolism in rainbow trout. Toxicol. Appl. Pharmacol. 251, 201-208. http://dx.doi.org/10.1016/j.taap.2010.12.013.

Puccia, E., Messina, C.M., Cangialosi, M.V., D'Agati, P., Mansueto, C., Pellerito, C., Nagy, L., Mansueto, V., Scopelliti, M., Fiore, T., Pellerito, L., 2005. Lipid and fatty acid variations in Ciona intestinalis ovary after tri-n-butyltin (IV) chloride exposure. Appl. Organomet. Chem. 19, 23-29. http://dx.doi.org/10.1002/aoc.765.

Riu, A., le Maire, A., Grimaldi, M., Audebert, M., Hillenweck, A., Bourguet, W., Balaguer, P., Zalko, D., 2011. Characterization of novel ligands of ER $\alpha, \operatorname{Er} \beta$, and PPAR $\gamma$ : the case of halogenated bisphenol A and their conjugated metabolites. Toxicol. Sci. 122, 372-382. http://dx.doi.org/10.1093/toxsci/kfr132.

Riu, A., Mccollum, C.W., Pinto, C.L., Grimaldi, M., Hillenweck, A., Perdu, E., Zalko, D., Bernard, L., Laudet, V., Balaguer, P., Bondesson, M., Gustafsson, J.A., 2014. Halogenated bisphenol-A analogs act as obesogens in zebrafish larvae (Danio rerio). Toxicol. Sci. 139, 48-58. http://dx.doi.org/10.1093/toxsci/kfu036.

Rodrigues, P., Reis-Henriques, M.A., Campos, J., Santos, M.M., 2006. Urogenital papilla feminization in male Pomatoschistus minutus from two estuaries in northwestern Iberian Peninsula. Mar. Environ. Res. 62, 258-262. http://dx.doi.org/10.1016/j. marenvres.2006.04.032

Runnalls, T.J., Hala, D.N., Sumpter, J.P., 2007. Preliminary studies into the effects of the human pharmaceutical Clofibric acid on sperm parameters in adult fathead minnow. Aquat. Toxicol. 84, 111-118. http://dx.doi.org/10.1016/j.aquatox.2007.06.005.

Runnalls, T.J., Beresford, N., Kugathas, S., Margiotta-Casaluci, L., Scholze, M., Scott, A.P., Sumpter, J.P., 2015. From single chemicals to mixtures-reproductive effects of levonorgestrel and ethinylestradiol on the fathead minnow. Aquat. Toxicol. 169, 152-167. http://dx.doi.org/10.1016/j.aquatox.2015.10.009.

Sadekarpawar, S., Parikh, P., 2013. Gonadosomatic and Hepatosomatic Indices of Freshwater Fish Oreochromis mossambicus in Response to a Plant Nutrient 8, 110-118. http://dx.doi.org/10.5829/idosi.wjz.2013.8.1.7268.

Sancho, E., Ferrando, M.D., Andreu, E., 1998. Effects of sublethal exposure to a pesticide on levels of energetic compounds in Anguilla anguilla. J. Environ. Sci. Health B 33, 411-424. http://dx.doi.org/10.1080/03601239809373154.

Sancho, E., Villarroel, M.J., Andreu, E., Ferrando, M.D., 2009. Disturbances in energy metabolism of Daphnia magna after exposure to tebuconazole. Chemosphere 74, 1171-1178. http://dx.doi.org/10.1016/j.chemosphere.2008.11.076.

Santos, M., Reis-Henriques, M., Castro, L., 2012. Chapter 7. Lipid homeostasis perturbation by organotins: effects on vertebrates and invertebrates. In: Biochemical and 
Physiological Effects of Organotins, pp. 83-96. http://dx.doi.org/10.2174/ 978160805265311201010083.

Sárria, M.P., Santos, M.M., Castro, L.F.C., Vieira, N.M., Monteiro, N.M., 2013. Estrogenic chemical effects are independent from the degree of sex role reversal in pipefish. J. Hazard. Mater. 263, 746-753. http://dx.doi.org/10.1016/j.jhazmat.2013.10.043.

Schlezinger, J.J., Howard, G.J., Hurst, C.H., Emberley, J.K., Waxman, D.J., Webster, T., Sherr, D.H., 2004. Environmental and endogenous peroxisome proliferator-activated receptor $\mathrm{g}$ agonists induce bone marrow $\mathrm{B}$ cell growth arrest and apoptosis: interactions between mono (2-ethylhexyl)phthalate, 9-cis-retinoic acid, and 15-deoxy$\Delta$ 12,14-prostaglandin J21. J. Immunol. 173, 3165-3177. http://dx.doi.org/10.4049/ jimmunol.173.5.3165.

Schug, T.T., Janesick, A., Blumberg, B., Heindel, J.J., 2011. Endocrine disrupting chemicals and disease susceptibility. J. Steroid Biochem. Mol. Biol. 127, 204-215. http://dx.doi.org/10.1016/j.jsbmb.2011.08.007.

Schug, T.T., Johnson, A.F., Birnbaum, L.S., Colborn, T., Guillette, L.J., Crews, D.P., Collins, T., Soto, A.M., vom Saal, F.S., McLachlan, J.A., Sonnenschein, C., Heindel, J.J., 2016. Minireview: endocrine disruptors: past lessons and future directions. Mol. Endocrinol. 30, 833-847. http://dx.doi.org/10.1210/me.2016-1096.

Shi, Y., Burn, P., 2004. Lipid metabolic enzymes: emerging drug targets for the treatment of obesity. Nat. Rev. Drug Discov. 3, 695-710. http://dx.doi.org/10.1038/nrd1469.

Sladek, F.M., 2011. What are nuclear receptor ligands? Mol. Cell. Endocrinol. 334, 3-13. http://dx.doi.org/10.1016/j.mce.2010.06.018.

Soares, J., Coimbra, A.M., Reis-Henriques, M.A., Monteiro, N.M., Vieira, M.N., Oliveira, J.M.A., Guedes-Dias, P., Fontaínhas-Fernandes, A., Parra, S.S., Carvalho, A.P., Castro, L.F.C., Santos, M.M., 2009. Disruption of zebrafish (Danio rerio) embryonic development after full life-cycle parental exposure to low levels of ethinylestradiol. Aquat. Toxicol. 95, 330-338. http://dx.doi.org/10.1016/j.aquatox.2009.07.021.

Somm, E., Schwitzgebel, V.M., Toulotte, A., Cederroth, C.R., Combescure, C., Nef, S. Aubert, M.L., Hüppi, P.S., 2009. Perinatal exposure to bisphenol a alters early adipogenesis in the rat. Environ. Health Perspect. 117, 1549-1555. http://dx.doi.org/ $10.1289 / \mathrm{ehp} .11342$

Sumpter, J.P., 2005. Endocrine disrupters in the aquatic environment: an overview. Acta Hydrochim. Hydrobiol. 33, 9-16. http://dx.doi.org/10.1002/aheh.200400555.

Suryavanshi, U., Sreepada, R.A., Ansari, Z.A., Nigam, S., Badesab, S., 2009. A study on biochemical changes in the penaeid shrimp, Metapenaeus monoceros (Fabricius) following exposure to sublethal doses of organochlorine pesticide (endosulfan). Chemosphere 77, 1540-1550. http://dx.doi.org/10.1016/j.chemosphere.2009.09. 051.

Takeuchi, S., Matsuda, T., Kobayashi, S., Takahashi, T., Kojima, H., 2006. In vitro screening of 200 pesticides for agonistic activity via mouse peroxisome proliferatoractivated receptor (PPAR) $\alpha$ and PPAR $\gamma$ and quantitative analysis of in vivo induction pathway. Toxicol. Appl. Pharmacol. 217, 235-244. http://dx.doi.org/10.1016/j. taap.2006.08.011.

TEDX, 2017. The endocrine disrupting exchange [WWW document]. URL. http://www endocrinedisruption.org/endocrine-disruption/tedx-list-of-potential-endocrinedisruptors $/$ chemicalsearch?action $=$ search $\&$ sall $=1$ (accessed 2.10.17)

Thornton, J.W., 2003. Nonmammalian nuclear receptors: evolution and endocrine disruption. Pure Appl. Chem. 75, 1827-1839. http://dx.doi.org/10.1351/ pac200375111827.

Tingaud-Sequeira, A., Ouadah, N., Babin, P.J., 2011. Zebrafish obesogenic test: a tool for screening molecules that target adiposity. J. Lipid Res. 52, 1765-1772. http://dx.doi. org/10.1194/jlr.D017012.

Titley-O'Neal, C.P., Spade, D.J., Zhang, Y., Kan, R., Martyniuk, C.J., Denslow, N.D., MacDonald, B.A., 2013. Gene expression profiling in the ovary of queen conch (Strombus gigas) exposed to environments with high tributyltin in the British Virgin Islands. Sci. Total Environ. 449, 52-62. http://dx.doi.org/10.1016/j.scitotenv.2013. 01.028.

Uren-Webster, T.M., Lewis, C., Filby, A.L., Paull, G.C., Santos, E.M., 2010. Mechanisms of toxicity of di(2-ethylhexyl) phthalate on the reproductive health of male zebrafish Aquat. Toxicol. 99, 360-369. http://dx.doi.org/10.1016/j.aquatox.2010.05.015.

Velasco-Santamaría, Y.M., Korsgaard, B., Madsen, S.S., Bjerregaard, P., 2011. Bezafibrate, a lipid-lowering pharmaceutical, as a potential endocrine disruptor in male zebrafish (Danio rerio). Aquat. Toxicol. 105, 107-118. http://dx.doi.org/10.1016/j.aquatox.
2011.05.018.

Verhaegen, Y., Parmentier, K., Swevers, L., Renders, E., Rougé, P., De Coen, W., Cooreman, K., Smagghe, G., 2011. The heterodimeric ecdysteroid receptor complex in the brown shrimp Crangon crangon: EcR and RXR isoform characteristics and sensitivity towards the marine pollutant tributyltin. Gen. Comp. Endocrinol. 172, 158-169. http://dx.doi.org/10.1016/j.ygcen.2011.02.019.

Villarroel, M.J., Sancho, E., Ferrando, M.D., Andreu, E., 2003. Acute, chronic and sublethal effects of the herbicide propanil on Daphnia magna. Chemosphere 53, 857-864. http://dx.doi.org/10.1016/S0045-6535(03)00546-0.

Villarroel, M.J., Sancho, E., Andreu-Moliner, E., Ferrando, M.D., 2013. Caloric content of Daphnia magna as reflect of propanil stress during a short-term exposure and its relationship to long-term responses. Environ. Toxicol. Pharmacol. 35, 465-472. http:// dx.doi.org/10.1016/j.etap.2013.02.012.

Vogel, C., Marcotte, E.M., 2012. Insights into the regulation of protein abundance from proteomic and transcriptomic analyses. Nat. Publ. Group 13, 227-232. http://dx.doi. org/10.1038/nrg3185.

Vogeler, S., Galloway, T.S., Lyons, B.P., Bean, T.P., 2014. The nuclear receptor gene family in the Pacific oyster, Crassostrea gigas, contains a novel subfamily group. BMC Genomics 15, 369. http://dx.doi.org/10.1186/1471-2164-15-369.

Wang, Y.H., LeBlanc, G.A., 2009. Interactions of methyl farnesoate and related compounds with a crustacean retinoid X receptor. Mol. Cell. Endocrinol. 309, 109-116. http://dx.doi.org/10.1016/j.mce.2009.05.016.

Wang, Y.H., Kwon, G., Li, H., LeBlanc, G.A., 2011. Tributyltin synergizes with 20-hydroxyecdysone to produce endocrine toxicity. Toxicol. Sci. 123, 71-79. http://dx.doi. org $/ 10.1093 /$ toxsci/kfr154.

Xu, W., Liu, W., Shao, X., Jiang, G., Li, X., 2012. Effect of trichlorfon on hepatic lipid accumulation in crucian carp Carassius auratus gibelio. J. Aquat. Anim. Health 24, 185-194. http://dx.doi.org/10.1080/08997659.2012.675937.

Yamamoto, T., Yasuhara, A., Shiraishi, H., Nakasugi, O., 2001. Bisphenol A in hazardous waste landfill leachates. Chemosphere 42, 1999-2002. http://dx.doi.org/10.1016/ S0045-6535(00)00079-5.

Yang, O., Kim, H.L., Weon, J.-I., Seo, Y.R., 2015. Endocrine-disrupting chemicals: review of toxicological mechanisms using molecular pathway analysis. J. Cancer Prev. 20, 12-24. http://dx.doi.org/10.15430/JCP.2015.20.1.12.

Zaya, R.M., Amini, Z., Whitaker, A.S., Ide, C.F., 2011a. Exposure to atrazine affects the expression of key genes in metabolic pathways integral to energy homeostasis in Xenopus laevis tadpoles. Aquat. Toxicol. 104, 254-262. http://dx.doi.org/10.1016/j aquatox.2011.04.022

Zaya, R.M., Amini, Z., Whitaker, A.S., Kohler, S.L., Ide, C.F., 2011b. Atrazine exposure affects growth, body condition and liver health in Xenopus laevis tadpoles. Aquat. Toxicol. 104, 243-253. http://dx.doi.org/10.1016/j.aquatox.2011.04.021.

Zhang, J., Zuo, Z., He, C., Cai, J., Wang, Y., Chen, Y., Wang, C., 2009. Effect of tributyltin on testicular development in Sebastiscus marmoratus and the mechanism involved. Environ. Toxicol. Chem. 28, 1528-1535. http://dx.doi.org/10.1897/08-347.1.

Zhang, W., Zhang, Y., Zhang, H., Wang, J., Cui, R., Dai, J., 2012. Sex Differences in Transcriptional Expression of FABPs in Zebra Fish Liver After Chronic Perfluorononanoic Acid Exposure. http://dx.doi.org/10.1021/es300147w.

Zhang, J., Zuo, Z., Xiong, J., Sun, P., Chen, Y., Wang, C., 2013. Tributyltin exposure causes lipotoxicity responses in the ovaries of rockfish, Sebastiscus marmoratus. Chemosphere 90, 1294-1299. http://dx.doi.org/10.1016/j.chemosphere.2012.10. 078

Zhang, J., Sun, P., Yang, F., Kong, T., Zhang, R., 2016. Tributyltin disrupts feeding and energy metabolism in the goldfish (Carassius auratus). Chemosphere 152, 221-228. http://dx.doi.org/10.1016/j.chemosphere.2016.02.127.

Zhong, H., Dong, L., Dong, Q., Ke, C., Fu, J., Wang, X., Liu, C., Dai, L., 2012. Quantitative analysis of aberrant fatty acid composition of zebrafish hepatic lipids induced by organochlorine pesticide using stable isotope-coded transmethylation and gas chromatography-mass spectrometry. Anal. Bioanal. Chem. 404, 207-216. http://dx.doi. org/10.1007/s00216-012-6089-1.

Zhu, Q.L., Luo, Z., Zhuo, M.Q., Tan, X.Y., Sun, L.D., Zheng, J.L., Chen, Q.L., 2014. In vitro exposure to copper influences lipid metabolism in hepatocytes from grass carp (Ctenopharyngodon idellus). Fish Physiol. Biochem. 40, 595-605. http://dx.doi.org/ 10.1007/s10695-013-9869-4. 